University of Montana

ScholarWorks at University of Montana

Chemistry and Biochemistry Faculty

Publications

Chemistry and Biochemistry

$10-16-2014$

\title{
Aerosol emissions from prescribed fires in the United States: A synthesis of laboratory and aircraft measurements
}

\author{
A. A. May \\ Ohio State University - Main Campus \\ G. R. McMeeking \\ Colorado State University - Fort Collins \\ T. Lee \\ Colorado State University - Fort Collins \\ J. W. Taylor \\ University of Manchester \\ J. S. Craven \\ California Institute of Technology \\ See next page for additional authors
}

Follow this and additional works at: https://scholarworks.umt.edu/chem_pubs

Part of the Biochemistry Commons, and the Chemistry Commons

Let us know how access to this document benefits you.

\section{Recommended Citation}

May, A. A., et al. (2014), Aerosol emissions fromprescribed fires in the United States: A synthesis of laboratory and aircraft measurements, J. Geophys. Res. Atmos., 119, 11,826-11,849, doi:10.1002/ 2014JD021848.

This Article is brought to you for free and open access by the Chemistry and Biochemistry at ScholarWorks at University of Montana. It has been accepted for inclusion in Chemistry and Biochemistry Faculty Publications by an authorized administrator of ScholarWorks at University of Montana. For more information, please contact

scholarworks@mso.umt.edu. 


\section{Authors}

A. A. May, G. R. McMeeking, T. Lee, J. W. Taylor, J. S. Craven, I. R. Burling, A. P. Sullivan, Sheryl Kashi Akagi, J. L. Collett Jr., M. Flynn, H. Coe, S. P. Urbanski, J. H. Seinfeld, Robert Yokelson, and S. M. Kreidenweis 


\section{Journal of Geophysical Research: Atmospheres}

\section{RESEARCH ARTICLE \\ 10.1002/2014JD021848 \\ Key Points: \\ Aerosol emissions from prescribed fires in the United States: A synthesis of laboratory and aircraft measurements}

- Laboratory experiments represent aircraft measurements reasonably well - Black carbon emissions in inventories may require upward revision

Correspondence to:

S. M. Kreidenweis,

sonia@atmos.colostate.edu

Citation:

May, A. A., et al. (2014), Aerosol emissions from prescribed fires in the United States: A synthesis of laboratory and aircraft measurements, J. Geophys. Res. Atmos., 119, 11,826-11,849, doi:10.1002/ 2014JD021848.

Received 31 MAR 2014 Accepted 18 SEP 2014 Accepted article online 22 SEP 2014 Published online 16 OCT 2014 Laboratory, United States Forest Service, Missoula, Montana, USA

\author{
A. A. May ${ }^{1,2}$, G. R. McMeeking 1,3 , T. Lee ${ }^{1,4}$, J. W. Taylor ${ }^{5}$, J. S. Craven ${ }^{6}$, I. Burling ${ }^{7,8}$, A. P. Sullivan ${ }^{1}$, \\ S. Akagi ${ }^{8}$, J. L. Collett Jr. ${ }^{1}$, M. Flynn ${ }^{5}$, H. Coe $^{5}$, S. P. Urbanski ${ }^{9}$, J. H. Seinfeld ${ }^{6}$, R. J. Yokelson ${ }^{8}$, \\ and S. M. Kreidenweis ${ }^{1}$
}

${ }^{1}$ Department of Atmospheric Science, Colorado State University, Fort Collins, Colorado, USA, ${ }^{2}$ Now at Department of Civil, Environmental, and Geodetic Engineering, Ohio State University, Columbus, Ohio, USA, ${ }^{3}$ Now at Droplet Measurement Technologies, Inc., Boulder, Colorado, USA, ${ }^{4}$ Now at Department of Environmental Science, Hankuk University of Foreign Studies, Seoul, South Korea, ${ }^{5}$ Centre for Atmospheric Science, University of Manchester, Manchester, UK, ${ }^{6}$ Division of Chemistry and Chemical Engineering, California Institute of Technology, Pasadena, California, USA, ${ }^{7}$ Now at Cytec Canada, Niagara Falls, Ontario, Canada, ${ }^{8}$ Department of Chemistry, University of Montana, Missoula, Montana, USA, ${ }^{9}$ Fire Sciences

\begin{abstract}
Aerosol emissions from prescribed fires can affect air quality on regional scales. Accurate representation of these emissions in models requires information regarding the amount and composition of the emitted species. We measured a suite of submicron particulate matter species in young plumes emitted from prescribed fires (chaparral and montane ecosystems in California; coastal plain ecosystem in South Carolina) and from open burning of over 15 individual plant species in the laboratory. We report emission ratios and emission factors for refractory black carbon $(\mathrm{rBC})$ and submicron nonrefractory aerosol and compare field and laboratory measurements to assess the representativeness of our laboratory-measured emissions. Laboratory measurements of organic aerosol (OA) emission factors for some fires were an order of magnitude higher than those derived from any of our aircraft observations; these are likely due to higher-fuel moisture contents, lower modified combustion efficiencies, and less dilution compared to field studies. Nonrefractory inorganic aerosol emissions depended more strongly on fuel type and fuel composition than on combustion conditions. Laboratory and field measurements for $\mathrm{rBC}$ were in good agreement when differences in modified combustion efficiency were considered; however, rBC emission factors measured both from aircraft and in the laboratory during the present study using the Single Particle Soot Photometer were generally higher than values previously reported in the literature, which have been based largely on filter measurements. Although natural variability may account for some of these differences, an increase in the BC emission factors incorporated within emission inventories may be required, pending additional field measurements for a wider variety of fires.
\end{abstract}

\section{Introduction}

Prescribed fires are open biomass burning (BB) activities that may result in negative anthropogenic impacts on local-to-regional air quality and climate. Despite its potential drawbacks, prescribed fire is often the best option for maintaining and restoring native, fire-adapted ecosystems [Carter and Foster, 2004]. Conversely, fire suppression and/or the absence of prescribed fire can increase fuel loads above natural levels and potentially increase the likelihood of extreme wildfires [Fernandes and Botelho, 2003; Flannigan et al., 2009] and their associated negative impacts on ecosystems [Miller et al., 2008], climate [Westerling et al., 2006], and air quality [Spracklen et al., 2009]. Particulate emissions from prescribed fires play a major role in determining their atmospheric impacts. Smoke from wildfires and prescribed fires has been shown to increase particulate matter (PM) concentrations in urban areas [Phuleria et al., 2005; Hu et al., 2008; Liu et al., 2009] and degrade visibility on regional scales [McMeeking et al., 2006; Park et al., 2007].

The major PM species emitted from fires are primary organic aerosol (OA) and black carbon (BC), though inorganic components such as nitrate $\left(\mathrm{NO}_{3}{ }^{-}\right)$, sulfate $\left(\mathrm{SO}_{4}{ }^{2-}\right)$, ammonium $\left(\mathrm{NH}_{4}{ }^{+}\right)$, chloride (denoted as $\mathrm{Chl}{ }^{-}$, per the Aerodyne Aerosol Mass Spectrometer community nomenclature), potassium $\left(\mathrm{K}^{+}\right)$, and sodium $\left(\mathrm{Na}^{+}\right)$ can be important depending on the fire/fuel type [Reid et al., 2005; Hosseini et al., 2013]. The open burning of biomass (e.g., forests, fields, savannas, and urban/rural waste, but excluding cooking fires and biofuels) 
generates approximately $40 \%$ of the mass of globally averaged annual submicron BC aerosol emissions and $65 \%$ of primary submicron organic carbon (OC) emissions [Bond et al., 2013]. BC absorbs light over a broad range of wavelengths, and its presence in the atmosphere has significant effects on the radiative balance of the atmosphere, snow and ice albedo, and visibility [Ramanathan and Carmichael, 2008; Bond et al., 2013]. Organic aerosol primarily scatters light, but some components emitted by fires have been shown to also absorb light strongly at near-UV wavelengths [Kirchstetter et al., 2004; Andreae and Gelencsér, 2006; Lewis et al., 2008; Magi, 2009; Lack et al., 2012; Saleh et al., 2013]. Chemical transport models used to predict regional air quality and global climate impacts require accurate $\mathrm{BC}$ emission inventories to correctly simulate column BC loading and absorption aerosol optical depth [Koch et al., 2009]. These models also require accurate estimates of $\mathrm{OA}$ emissions and an appropriate treatment for the partitioning of semivolatile species and for secondary production of additional OA from oxidation of primary emissions [Robinson et al., 2007, 2010; Grieshop et al., 2009b; Hennigan et al., 2011; May et al., 2013; Ortega et al., 2013].

Two approaches are commonly used to create emission inventories for BB: "bottom up," in which total emissions are calculated by multiplying the mass of biomass consumed by an emission factor (EF, $\mathrm{g}$ species emitted per kg fuel burned), and "top down," in which the emissions are inferred from the amount required to reproduce the observed loading in the atmosphere, accounting for other sources. Major uncertainties for either approach are that fires and their emissions can be difficult to detect via satellite [Wiedinmyer et al., 2006, 2011; van der Werf et al., 2010] due to clouds, orbital gaps, sensitivity, and other problems [Giglio et al., 2013], that BB emissions have not been fully characterized (i.e., not all emitted compounds have been identified) [Yokelson et al., 2013a], and that the processes affecting atmospheric physicochemical aging of BB emissions are not completely understood [Jimenez et al., 2009; Akagi et al., 2012; Heilman et al., 2014].

Emission factors for BB have been measured in the laboratory, from aircraft, and on the ground for many years, and have been compiled elsewhere [e.g., Andreae and Merlet, 2001; Akagi et al., 2011]. Many previous biomass burning BC and OA emission measurements used filter-based light absorption [e.g., Paris et al., 2009] or thermal-optical analysis [e.g., Formenti et al., 2003] to quantify emissions from fires. However, these measurement techniques often disagree, by factors as large as 4, even for the same filters when analyzed via different protocols [Watson et al., 2005; McMeeking et al., 2009]. Further, different approaches yield different operationally defined carbonaceous aerosol, although the terminology has been inappropriately substituted in the literature; light absorption techniques provide measurements of $B C$, while thermal-optical analyses provide measurements of elemental carbon (EC).

Both approaches have associated complications. The presence of light-absorbing organic material frequently found in BB emissions impacts filter-based approaches because the light-absorbing organic material can be erroneously interpreted as BC [Kirchstetter et al., 2004], or the organic material biases the absorption measurement itself due to coating effects [Subramanian et al., 2007; Cappa et al., 2008; Lack et al., 2008]. Thermal-optical analyses may differ due to various factors (e.g., instrument model and analysis protocol), which may affect the charring of organic carbon (OC) and the OC/EC split [e.g., Yu et al., 2002; Chow et al., $2004,2007]$. Further, filter-based measurements typically cannot provide any information regarding the particle size distribution of uncoated BC "cores," which, together with its mixing state, will affect the atmospheric lifetime and aerosol optical properties of the BC particles [Bond and Bergstrom, 2006; Lack and Cappa, 2010; Lack et al., 2012; Bond et al., 2013].

The development of highly sensitive continuous or semicontinuous instruments such as the Droplet Measurement Technologies (DMT) Single Particle Soot Photometer (SP2) and Aerodyne Aerosol Mass Spectrometer (AMS) has provided the ability to measure refractory $B C(\mathrm{rBC})$ mass concentrations and nonrefractory submicron particulate mass concentrations (including $O A$ ), respectively, in the absence of a filter medium, avoiding many artifacts associated with filter sampling. The SP2 provides a different measure of BC compared to absorption measurements by quantifying the refractory material in the absorbing aerosol [Slowik et al., 2007; McMeeking et al., 2010; Liu et al., 2011; Petzold et al., 2013], whereas BC mass concentrations estimated using absorption methods are sensitive to the presence of coatings and/or organic species affecting light absorption [Subramanian et al., 2007; Cappa et al., 2008; Lack et al., 2008]. Hence, we use " $\mathrm{rBC}$ " to refer to the operationally defined measurements from the SP2, while "BC" refers to estimates made using any light absorption technique. There have been few comparisons between $\mathrm{rBC}$ mass concentrations measured by the SP2 and BC mass concentrations measured by the thermal-optical methods 
on which many BB emission estimates are based [e.g., Andreae and Merlet, 2001]. Several studies have compared BC measured by several different techniques, including thermal-optical analysis and the SP2 [e.g., Slowik et al., 2007; Kondo et al., 2011a; Yelverton et al., 2014], but did not examine biomass burning samples directly, so it is unclear how to infer how well BB emission factors from the filter-based approach and SP2 compare. Thus, the poor constraints on BC emission factors arising from previous measurement methods and limited observations remain a significant source of uncertainty in emission estimates [e.g., Bond et al., 2013]. It is therefore of interest to measure $\mathrm{rBC}$ emission factors from BB using the SP2 for comparison with earlier estimates.

The SP2 has been previously used to measure rBC concentrations and physical properties in the atmosphere, including some sampling of biomass burning emissions [Schwarz et al., 2008; Spackman et al., 2008; Kondo et al., 2011b; Sahu et al., 2012; Dahlkötter et al., 2014]. Spackman et al. [2008] reported rBC emission ratios (ER) to excess carbon monoxide (CO) for a biomass burning plume encountered over Texas that were 25-75\% higher than those recommended for EC by Andreae and Merlet [2001] for extratropical fires and speculated that some of the differences may be due to variations in fuel burned although combustion efficiency plays the major role. Conversely, the ER observed by both Kondo et al. [2011b] and Sahu et al. [2012] were less than the values from Andreae and Merlet [2001]. This demonstrates that there is substantial variability in the $\mathrm{BC}$ emissions from $\mathrm{BB}$, and hence, there is clearly a need for additional measurements of $\mathrm{BC}$ emission factors.

Similarly, the AMS has been used to measure nonrefractory aerosol emissions from fires in several recent field campaigns focusing on biomass burning emissions [Capes et al., 2008; DeCarlo et al., 2008; Cubison et al., 2011; Hecobian et al., 2011; Akagi et al., 2012; Jolleys et al., 2012]. Emission ratios of OA from these studies agree within roughly a factor of 2 compared to compiled BB emission inventories [Andreae and Merlet, 2001; Akagi et al., 2011], although there may be substantial natural variability (i.e., the range of ER in the literature spans roughly 1 order of magnitude). To our knowledge, only one recent study [Akagi et al., 2012] has examined online PM emissions from prescribed fires in the U.S. at the source via airborne sampling using both SP2 and AMS; however, this work focused mainly on transformations of OA (e.g., physicochemical aging) for a single plume. Here we describe a new set of measurements of $r B C$ and nonrefractory PM in emissions from prescribed fires in the U.S., including well-characterized laboratory fires and aircraft measurements in young plumes from prescribed fires in California and South Carolina. Our goals are to examine the relationships between aerosol emissions and plant species, ecosystem, and fire combustion conditions in order to provide a reference set of EF and ER measurements for use in emission inventories for North American prescribed fires, and to examine reasons for any discrepancies between laboratory- and aircraft-measured emissions. Here we only present fire-averaged EF and ER, rather than investigating emissions during fire phases (e.g., flaming versus smoldering), as the average values are what are included in most emissions inventories [van der Werf et al., 2010; Wiedinmyer et al., 2011], and nearly all global chemical transport models that are used to predict atmospheric impacts of wildfires. Additionally, we provide mass equivalent particle diameters of uncoated $\mathrm{rBC}$ present in the emissions from these fires as these values can assist in predictions of aerosol radiative forcing in global climate models and size-resolved aerosol chemical composition in chemical transport models.

\section{Experiment Details}

We present results from a laboratory-based campaign in 2009 and aircraft campaigns in 2009 and 2011. The laboratory campaign took place at the United States (U.S.) Forest Service Fire Sciences Laboratory (FSL) in Missoula, Montana during the third Fire Laboratory At Missoula Experiment (FLAME-III). It was the third of a series of related, but independent, experiments at the FSL examining the properties of fire emissions. The aircraft campaigns focused on measuring emissions from prescribed fires over California (San Luis Obispo Biomass Burning Experiment; SLOBB) and South Carolina (South Carolina fiRe Emissions and Aging Measurements; SCREAM) in the U.S., summarized in Table 1. Each campaign featured extensive trace gas and aerosol instrumentation, but we only describe instruments directly relevant to the analysis presented in the following sections. Additional information regarding other measurements and experiments performed during these campaigns can be found elsewhere [Burling et al., 2011; Hennigan et al., 2011, 2012; Akagi et al., 2012, 2013, 2014; Engelhart et al., 2012; May et al., 2013; Ortega et al., 2013; Sullivan et al., 2014]. 


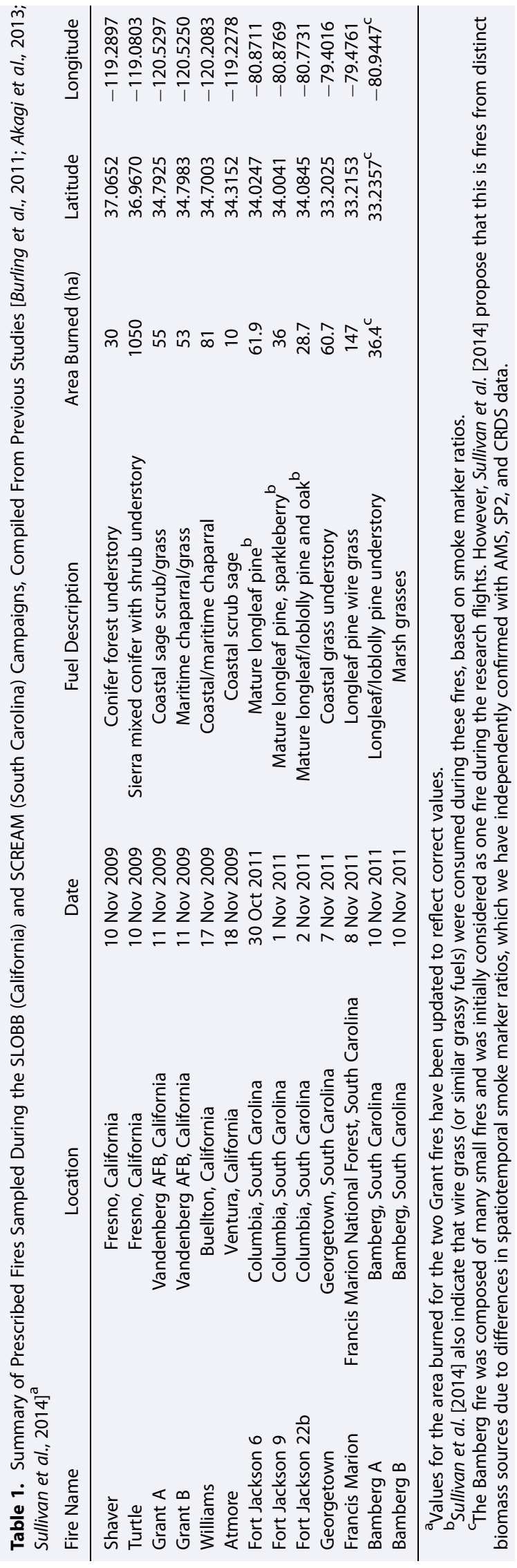

\subsection{Facilities, Fuels, and Site Descriptions} The FSL features an approximately $3000 \mathrm{~m}^{3}$ combustion chamber suitable for the measurement of gas and particle emissions from laboratory fires on timescales of several hours [Christian et al., 2003; McMeeking et al., 2009]. We conducted 27 burns, in which smoke emissions from the ignited biomass filled the sealed yet not airtight combustion chamber and were sampled by instruments located in adjacent laboratories to characterize primary emissions with no photochemical aging. Each burn experiment lasted approximately 3 hours. Smoke was actively mixed within the room by a large fan located on the floor. The emissions were fire integrated for the duration of the experiment after the room had become well mixed (since the smoke was retained within the combustion chamber) to remove potential initial biases since gases diffuse faster than particles.

Plant species burned during FLAME-III were mostly those commonly consumed in prescribed fires and wildfires in the United States [Christian et al., 2003; McMeeking et al., 2009] and are listed in Table 2. They included several species common to maritime chaparral, Sierra Nevada montane, and southeastern (SE) U.S. coastal plain ecosystems where prescribed fire measurements took place during the aircraft studies. Fuels burned during laboratory experiments were conditioned in a lowhumidity chamber for at least one night prior to being burned, as described by McMeeking et al. [2009]; fuel moisture contents prior to combustion are provided in Table 2. The total fuel mass and the mass of fuel remaining after combustion were measured as a function of time from ignition using a Mettler-Toledo PM34 balance. Fuels were ignited using a heated wire bed treated with ethanol, as described in McMeeking et al. [2009].

We performed the airborne measurements on a U.S. Forest Service DHC-6 Twin Otter aircraft modified for atmospheric sampling. SLOBB consisted of eight research flights that examined emissions from six different prescribed fires whose locations in central California are shown in Figure 1a and listed in Table 1. SCREAM featured nine research flights that examined emissions from prescribed fires at six locations in South Carolina, shown in 
Table 2. Types and Characteristics of Fuels Burned During the FLAME-III Laboratory Experiments ${ }^{a}$

\begin{tabular}{|c|c|c|c|c|c|c|}
\hline Common Name & Scientific Name & Ecosystem Type & IDs & $\begin{array}{l}\text { Carbon Fraction } \\
\text { (Dry Weight \%) }\end{array}$ & $\begin{array}{l}\text { Moisture Content } \\
\text { (Dry Weight \%) }\end{array}$ & $\begin{array}{l}\text { Initial Fuel } \\
\text { Mass (g) }\end{array}$ \\
\hline Alaskan duff & Multiple species & boreal & 51 & 47.6 & 19.2 & 200 \\
\hline Black spruce & Picea mariana & boreal & 39 & 53.7 & 10.9 & 250 \\
\hline Ceanothus & Ceanothus L. & chaparral & 62 & 53.2 & 9.9 & 1002 \\
\hline Chamise & Adenostoma fasciculatum & chaparral & 59 & 55.3 & 10.0 & 500 \\
\hline \multirow[t]{2}{*}{ Gallberry } & Ilex glabra & SE coastal plain & 44 & 55.6 & 39.3 & 500 \\
\hline & & & 47 & & 63.3 & 500 \\
\hline \multirow[t]{3}{*}{ Lodgepole pine } & Pinus contorta & montane & 38 & 54.3 & 45.5 & 250 \\
\hline & & & 50 & & 82.8 & 150 \\
\hline & & & 61 & & 60.7 & 203 \\
\hline \multirow[t]{2}{*}{ Manzanita } & Arctostaphylos spp. & chaparral & 54 & 54.3 & 11.1 & 500 \\
\hline & & & 60 & & 8.4 & 502 \\
\hline Peat & multiple species & Indonesian peat & 64 & 60.4 & 177.7 & 344 \\
\hline \multirow[t]{2}{*}{ Pocosin } & multiple species & palustrine wetland & 41 & 54.5 & 9.1 & 400 \\
\hline & & & 63 & & 8.4 & 799 \\
\hline \multirow[t]{3}{*}{ Ponderosa pine } & Pinus ponderosa & montane & 40 & 55.4 & 74.2 & 250 \\
\hline & & & 48 & & 84.2 & 200 \\
\hline & & & 57 & & 77.6 & 201 \\
\hline \multirow[t]{2}{*}{ Sagebrush } & Artemisia tridentate & sage scrubland & 49 & 51.5 & 15.5 & 300 \\
\hline & & & 53 & & 15.6 & 300 \\
\hline \multirow[t]{2}{*}{ Saw grass } & Cladium jamaicense & Everglades & 43 & 50.7 & 10.8 & 350 \\
\hline & & & 58 & & 8.0 & 525 \\
\hline \multirow[t]{2}{*}{ Turkey oak } & Quercus laevis & SE coastal plain & 45 & 52.5 & 11.4 & 400 \\
\hline & & & 52 & & 42.8 & 401 \\
\hline Wheat straw & Triticum spp. & agricultural & 46 & 47.1 & 9.0 & 500 \\
\hline White spruce & Picea glauca & boreal & 55 & 52.9 & 9.0 & 346 \\
\hline \multirow{2}{*}{ Wire grass } & Aristida stricta & SE coastal plain & 42 & 50.9 & 29.4 & 600 \\
\hline & & & 56 & & 12.1 & 500 \\
\hline
\end{tabular}

\footnotetext{
${ }^{\mathrm{a}}$ Fuel carbon fraction and moisture contents are expressed as percentages of dry mass. Identification numbers refer to specific burns during FLAME-III.
}

Figure 1b and also listed in Table 1. Akagi et al. [2012, 2013] and Burling et al. [2011] described the aircraft platform, measurement systems, and fire characteristics during SLOBB and SCREAM in more detail. The aircraft had a maximum flight endurance of approximately $4 \mathrm{~h}$. Sampling for aerosol measurements was performed through a roof-mounted diffuser inlet [Yokelson et al., 2007] that was superisokinetic for typical aircraft sampling speeds (40-80 $\mathrm{m} \mathrm{s}^{-1}$ ), with maximum theoretical losses of $10 \%$ for submicron particles and $<5 \%$ for $0.5 \mu \mathrm{m}$ diameter particles and smaller. Supermicron particles were removed via an impactor with a cut size of $1 \mu \mathrm{m}$, so losses or enhancements of supermicron particles due to the sampling configuration could be neglected.

During SLOBB, the aircraft sampled four prescribed fires in maritime chaparral vegetation (designated as Grant A, Grant B, Williams, and Atmore, based on their location) and two prescribed fires in Sierra Nevada mixed-conifer vegetation (Turtle and Shaver). A detailed description of each fire including date, fuels, area burned, and trace gas emissions are provided by Burling et al. [2011] and in Table 1 (excluding emissions data), which includes corrected values of burned area for the Grant A and Grant B fires originally reported by Burling et al. [2011]. Akagi et al. [2012] described measurements performed for the Williams Fire, which was the target of two research flights to characterize initial emissions and subsequent aging processes. The SCREAM aircraft measurements included high-intensity prescribed fires at the Fort Jackson (FJ) military facility near Columbia, South Carolina. We sampled three fires located on the facility, referred to as FJ 6, FJ 9b, and FJ 22b after the name of the plot of land on the base where the fire occurred. These burns included detailed inventories of fuels consumed in the fires and complementary ground-based measurements [Aurell and Gullett, 2013; Yokelson et al., 2013a; Akagi et al., 2014]. The second half of the project examined three prescribed fires in the surrounding region (referred to as Georgetown, Francis Marion, and Bamberg based on their location), but since these fires supplemented the FJ work and were not planned in advance, there was less information regarding the fuels consumed in these fires, and there were no ground-based measurements. Consistent with the airborne smoke marker measurements of Sullivan et al. [2014], our independent data suggest that there are two distinct fires at the Bamberg location; Bamberg A appears likely to be attributed to needles while Bamberg B appears likely to be attributed to marsh grasses. Akagi et al. [2013] described the evolution of trace gases 

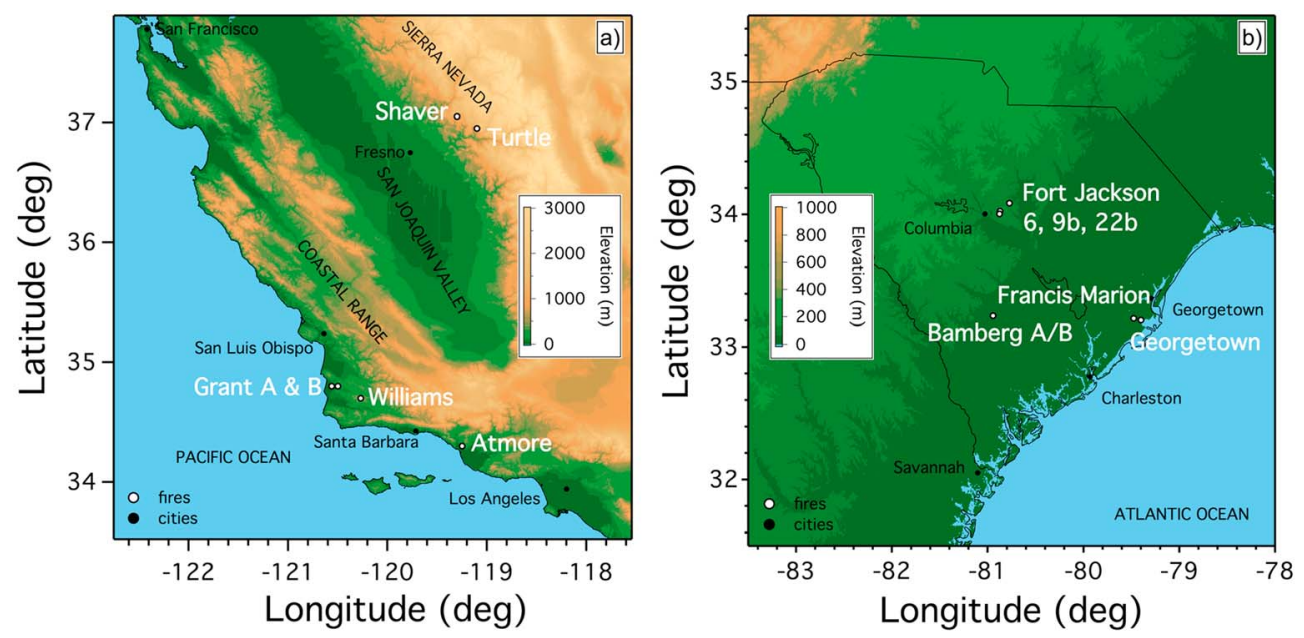

Figure 1. Topographic maps of (a) central California (SLOBB) and (b) South Carolina (SCREAM) showing locations of cities, prescribed fires, and major geographical features. Note the differences in elevation scales between the two panels. More details on fire location, area burned, and fuels consumed are provided in Table 1.

downwind of the fires investigated during SCREAM; here, we focus on characterization of aerosol species near the source. Atmospheric evolution of PM during SCREAM will be described in upcoming work.

\subsection{Refractory Black Carbon Measurements}

The SP2 (DMT, Inc., Boulder, Colorado) measures rBC particle mass using a laser-induced incandescence technique [Stephens et al., 2003] and has been deployed in a number of aircraft-, ground- and laboratory-based studies to examine rBC concentrations and properties [e.g., Baumgardner et al., 2004; Schwarz et al., 2006; Moteki et al., 2007; Liu et al., 2011]. The instrument illuminates particles with an intracavity Nd:YAG diode pumped laser $(\lambda=1064 \mathrm{~nm})$ with a Gaussian beam profile. Sampled particles containing sufficient absorbing material are heated to their vaporization temperature and emit radiation. While some metals present in biomass burning plumes (e.g., potassium) are strong absorbers at $1064 \mathrm{~nm}$, they are typically in the form of salts (e.g., $\mathrm{KCl}$ and $\mathrm{K}_{2} \mathrm{SO}_{4}$ ), which are nonabsorbing [Yamasoe et al., 2000]; furthermore, the absorption must be strong enough to heat the particle to temperatures in the range $3500-5000 \mathrm{~K}$ to be classified as rBC by the SP2 [Schwarz et al., 2006]. The emitted light is proportional to the $\mathrm{rBC}$ mass of individual particles, and the exact relationship is determined via calibration with a known mass of an atmospheric rBC proxy material [Baumgardner et al., 2012]. Several recent studies have investigated the SP2 response to different $\mathrm{rBC}$ proxy materials and found an approximately $30 \%$ variability in response depending on material [e.g., Moteki and Kondo, 2010]; furthermore, major atmospheric $\mathrm{rBC}$ particle types including diesel emissions, wood smoke, and ambient aerosol fell within a few percent of the range of responses to proxy materials [e.g., Laborde et al., 2012]. In all three campaigns, monodisperse proxy materials were generated via a Collison-type atomizer (TSI 3076; TSI, Inc., Shoreview, Minnesota) and differential mobility analyzer (TSI 3081). We used glassy carbon spheres (density $=1.42 \mathrm{~g} \mathrm{~cm}^{-3}$; Alfa Aesar, Ward Hill, Massachusetts) as the calibration material during the SLOBB and FLAME-III campaigns and fullerene soot (density $=0.5-0.9 \mathrm{~g} \mathrm{~cm}^{-3}$ ) during the SCREAM campaign. The SP2 response to these two materials may differ by up to $20 \%$; however, as there is considerable variability in recommended calibrations in the limited available literature [e.g., Moteki and Kondo, 2010, Figure 9], we have not applied a correction to our data. A BC density of $1.8 \mathrm{~g} \mathrm{~cm}^{-3}$ was assumed based on Bond and Bergstrom [2006] and was used to convert the mass of a single particle to its volume (assuming spherical particles), similar to Gysel et al. [2011].

We did not optimize the gain settings on the SP2 incandescence detectors to examine the rBC vaporization temperature or color ratio over the full size range but instead improved the sizing resolution of the system. $\mathrm{A}$ faulty amplifier board on the high-gain detector caused a truncation of the incandescence signal for $\mathrm{rBC}$ particles with masses above $6 \mathrm{fg}$ (approximately $0.18 \mu \mathrm{m}$ mass equivalent diameter) during the FLAME-III measurements, so only the low-gain detector was used for sizing rBC particles above this size. Both detectors were fully operational during the aircraft campaigns. 
During the laboratory campaign, the SP2 sampled emissions alternately downstream of a thermal denuder or an unperturbed bypass line over 1 min intervals [McMeeking et al., 2014], but we restricted our analysis herein to bypass sampling periods. On the aircraft, the SP2 inlet system was modified to reduce coincidence errors due to the expected high-particle concentrations by providing a controlled, filtered, and dried dilution airflow of approximately 10:1. The SP2 data analysis procedures were also modified to account for the high concentrations of particles encountered in smoke plumes. Modifications included adding a routine to identify when more than one black carbon particle was detected within the acquisition window and controlling the instrument thresholds for particle detection in high-concentration environments either manually in real-time or in postprocessing. Refractory black carbon mass distributions were fit with lognormal functions to approximate $\mathrm{rBC}$ mass outside the instrument detection range $(0.070-0.600 \mu \mathrm{m}$ for $\mathrm{rBC}$ "cores" over our assumed density and operating parameters) and to infer the mass-median diameter of uncoated $\mathrm{rBC}$ particles $\left(\mathrm{MMD}_{\mathrm{rBC}}\right)$. We report all $\mathrm{rBC}$ mass concentrations after adjustments using these lognormal corrections, which typically resulted in an increase in mass concentration by a factor of 1-1.4. Following Schwarz et al. [2006], we assume 10\% uncertainty due to flow calibrations and $20 \%$ uncertainty in mass calibration factor, which combined provides an estimated net measurement uncertainty for the SP2 of roughly $25 \%$.

\subsection{Nonrefractory Submicron Aerosol Measurements}

Nonrefractory aerosol composition was measured by two Time-of-Flight Aerosol Mass Spectrometers (ToF-AMS). A compact ToF-AMS (c-ToF-AMS) [Drewnick et al., 2005] from the California Institute of Technology flew on the Twin Otter during the SLOBB measurements, and a high-resolution ToF-AMS (HR-ToF-AMS) [DeCarlo et al., 2006] from Colorado State University was used for the FLAME-III and SCREAM measurements. The c-ToF-AMS instrument has been deployed on several aircraft-measurement campaigns and has been described in detail elsewhere [Murphy et al., 2009; Sorooshian et al., 2010]; during SLOBB, the c-ToF-AMS-measured composition using ion time-of-flight (iTOF) "V-mode" in the mass spectrometer for $4 \mathrm{~s}$ out of every $12 \mathrm{~s}$ cycle (the remainder being in particle time-of-flight, pTOF, mode, data not shown here). During FLAME-III, the HR-ToF-AMS was operating in alternating iTOF "V-mode" and "W-mode" over 30 s intervals; here we report only "V-mode" data. For SCREAM, the HR-ToF-AMS was modified for flight operation by mounting it in two NSF/NCAR GV-type aircraft racks. The HR-ToF-AMS was operated over a 6 s cycle under iToF "V-mode". Data from both instruments were processed using the ToF-AMS software SQUIRREL [Allan et al., 2004; DeCarlo et al., 2006] and PIKA [Sueper et al., 2013] to obtain aerosol mass concentrations at standard temperature and pressure ( $\mu \mathrm{g} \mathrm{sm}^{-3}, 273.15 \mathrm{~K}$ and $1013.25 \mathrm{hPa}$ ). A particle filter (Pall, HEPA capsule P/N 12144) was placed in front of the AMS at various times throughout the flights to determine the signal interference from particle-free air. Measurement uncertainty for the mass concentration of each species was taken to be $\pm 30 \%$ for both AMS data sets [Bahreini et al., 2009].

Values of AMS collection efficiency (CE) applied to BB smoke vary in the literature between 0.5 and 1.0 [Weimer et al., 2008; Heringa et al., 2011; Akagi et al., 2012], either based on assumptions made in prior work or inferred from complementary measurements, which introduces some uncertainty in reported values. For the FLAME-III laboratory data, we assume a $C E=1$, consistent with the treatment of other biomass burning primary OA data from this study [Hennigan et al., 2011; May et al., 2013; Ortega et al., 2013]. A constant CE of 0.5 was applied to the C-ToF AMS data based on the traditional approach for accounting for CE in ambient data sets [Canagaratna et al., 2007] and following the treatment of SLOBB data in Akagi et al. [2012], but the HR-ToF AMS data during SCREAM were processed using a recently developed composition-dependent CE (CDCE) algorithm [Middlebrook et al., 2012]. During SCREAM, the calculated CDCE ranged from 0.5 to nearly 1.0; however, the campaign-average value was 0.53 with higher values for more organic-rich aerosol. Hence, the treatment of both airborne data sets was roughly equivalent. These assumptions introduce a bias (up to a factor of two) to intercomparisons between the laboratory and airborne measurements; however, in both cases, the CE has been either assumed or estimated, so there is some inherent uncertainty (up to a factor of 2) associated with these values.

For the c-ToF-AMS data analysis, adjustments were made to the default fragmentation table [Allan et al., 2004] for sulfate and nitrate ion fragment signals in the mass spectrum. Under high-aerosol loadings, such as in a smoke plume, the contributions of organic ions with the same nominal mass as inorganic ions can be higher than in the default fragmentation table. The sulfate ion fragment $\mathrm{SO}^{+}$at $\mathrm{m} / \mathrm{z} 48$ has little interference 
from organic fragments (even at high-aerosol loadings), so the contributions to sulfate from the three major remaining fragments $\left(\mathrm{SO}_{2}{ }^{+}, \mathrm{SO}_{3}{ }^{+}\right.$, and $\left.\mathrm{H}_{2} \mathrm{SO}_{4}{ }^{+}\right)$were reconstructed based on a linear relationship with the $\mathrm{SO}^{+}$during a period of low-organic interference from the same flight. The nitrate ion $\mathrm{NO}^{+}$at $\mathrm{m} / \mathrm{z} 30$ also has organic interference and was reconstructed in a similar manner with the other main nitrate ion, $\mathrm{NO}_{2}{ }^{+}$at $\mathrm{m} / \mathrm{z} 46$ [Bae et al., 2007]. For the HR-ToF-AMS, these issues do not apply, since it can usually resolve the inorganic and organic ions at the same nominal mass. Hereafter, we will simply refer to both the c-ToF-AMS and HR-ToF-AMS measurements as AMS measurements.

\subsection{Trace Gas Measurements}

During the laboratory campaign, mixing ratios of $\mathrm{CO}$ and $\mathrm{CO}_{2}$ were measured by a variable-range gas filter correlation analyzer (Thermo Environmental Model 48C; Thermo Fisher Scientific, Inc., Waltham, Massachusetts) and a nondispersive infrared (NDIR) gas analyzer (Li-Cor Model 6262; Li-Cor Biosciences, Lincoln, Nebraska), respectively. The gas analyzers were calibrated with standards of known concentrations before and after each burn experiment. The estimated accuracy/precision of the measurements was $1 \% / 0.1 \%$ for $\mathrm{CO}_{2}$ and $2 \% / 1 \%$ for $\mathrm{CO}$ [McMeeking et al., 2009]. During SLOBB aircraft measurements, $\mathrm{CO}_{2}$ mixing ratios were measured continuously by the NDIR gas analyzer at $0.5-1 \mathrm{~Hz}$ from the same inlet as the SP2. During the SCREAM aircraft measurements, $\mathrm{CO}_{2}, \mathrm{CO}, \mathrm{CH}_{4}$, and water vapor mixing ratios were measured by a cavity ring-down spectrometer (CRDS; Picarro G2401; Picarro, Inc., Santa Clara, California), calibrated in-flight with mixed $\mathrm{CO} / \mathrm{CO}_{2} / \mathrm{CH}_{4}$ standards, following Urbanski [2013].

An airborne Fourier transform infrared spectrometer system (AFTIR) collected "grab" samples outside and inside of the smoke plumes [Burling et al., 2011; Akagi et al., 2013]. Sample spectra were analyzed to determine mixing ratios of $\mathrm{CO}, \mathrm{CO}_{2}$, and additional gas-phase compounds described elsewhere [Burling et al., 2011; Akagi et al., 2012, 2013]. The AFTIR system detection limits ranged from 1 to 10 ppbv for most species depending on the spectral averaging time.

\subsection{Sampling and Analysis Procedures}

The aircraft sampling procedure varied from flight-to-flight, but the following general approach was used to characterize the fire emissions in most situations. The aircraft first sampled "fresh" emissions at the fire source over a range of altitudes up to a few thousand meters for up to $2 \mathrm{~h}$, and if air traffic control restrictions permitted, flew downwind of the fire to sample the aged but still relatively young emissions in a quasiLagrangian manner. Examples of flight tracks are provided elsewhere [Akagi et al., 2012, 2013]. Concentrations of the various species were measured across each plume intercept to obtain plume-integrated values. The measurements near the source were used to determine the emission ratios and emission factors for each species, as described below. There was no discernable effect of altitude on emission ratios or emission factors.

During the laboratory campaign, the excess mixing ratios (denoted by $\Delta$ ) were calculated by subtracting the background concentrations of $\mathrm{CO}, \mathrm{CO}_{2}, \mathrm{rBC}$, and AMS-measured components in the time interval immediately prior to fuel ignition. The background $\mathrm{CO}_{2}$ concentrations drifted slightly during each experiment, so there was some subjectivity and resulting uncertainty in calculating $\Delta \mathrm{CO}_{2}$, particularly for fires that did not emit much $\mathrm{CO}_{2}$. During aircraft measurements, time-dependent background concentrations were collected outside of the plume, as the background values varied with location over the duration of the flight.

Excess $\mathrm{CO}$ and $\mathrm{CO}_{2}$ molar mixing ratios were used to determine the modified combustion efficiency (MCE) [Yokelson et al., 1996]:

$$
\mathrm{MCE}=\frac{\Delta \mathrm{CO}_{2}}{\Delta \mathrm{CO}_{2}+\Delta \mathrm{CO}}
$$

Higher-MCE values indicate a greater contribution from flaming combustion emissions, and lower MCE values indicate a greater contribution from smoldering combustion emissions. We estimated the uncertainty in MCE during FLAME-III arising from the uncertainty in the background $\mathrm{CO}_{2}$ mixing ratio by comparing two independent calculations of MCE by separate project investigators (this work and Hennigan et al. [2011]). Agreement between the two measurements diverged as $\Delta \mathrm{CO}_{2}$ decreased due to low $\Delta \mathrm{CO}_{2}$ signal-to-noise over the background $\mathrm{CO}_{2}$ value. Differences in calculated $\mathrm{MCE}$ between the two independent approaches ranged from roughly $0.5 \%$ for MCE of $0.94-0.97$ to roughly $2 \%$ for MCE of $0.87-0.90$. 
Fire-averaged mass ER for each species $(\mathrm{X})$ were either directly calculated from the mass ratio of $\Delta \mathrm{X}$ to $\Delta \mathrm{CO}$ for emissions sampled in the laboratory or from the regression of the plume-integrated source samples during the aircraft measurements, with the $y$ intercept forced through zero, since all data were background corrected. Emission factors (EF), which relate the mass of $X$ emitted to the mass of dry-fuel consumed, were calculated using the carbon mass balance method [Ward and Hardy, 1991]. In this work, we report both ER and $\mathrm{EF}$; both can be used to estimate total fresh emissions, and they are interchangeable if the emission factor of $\mathrm{CO}\left(\mathrm{EF}_{\mathrm{CO}}\right)$ is known. As plumes dilute, their concentrations normalized to $\mathrm{CO}$ can be compared to ER as a probe of physicochemical evolution [de Gouw et al., 2008; Bahreini et al., 2009; DeCarlo et al., 2010; Akagi et al., 2013]. Furthermore, $\mathrm{CO}$ is a more robust tracer for long-range transport of biomass burning emissions [e.g., Yokelson et al., 2009; Cubison et al., 2011] since $\mathrm{CO}_{2}$ may be lost due to uptake by plants and bodies of water. The use of ER also removes the need for any a priori knowledge of the sampled fire that are required to calculate EF (e.g., carbon content of the fuel) or implement EF into chemical transport models (e.g., area burned, fuel loading within the area, and fraction of fuel consumed).

Measurements of $\Delta \mathrm{CO}$ and $\Delta \mathrm{CO}_{2}$ were used to estimate the total carbon emitted during the laboratory experiments, but the aircraft total carbon estimates also included carbon in gases measured by the AFTIR system. Neglecting carbon mass in compounds not detected by the AFTIR system and in particles generally overestimates the emission factors by only $1-2 \%$ due to the small amount of carbon present in particles and gases other than $\mathrm{CH}_{4}, \mathrm{CO}$, and $\mathrm{CO}_{2}$, although in certain cases, carbon contained in the aerosol and nonmethane organic gases can represent a nonnegligible contribution [Watson et al., 2011; Yokelson et al., 2013a]. For the airborne measurements described during this work, $\mathrm{CO}$ and $\mathrm{CO}_{2}$ represented $>97 \%$ of total measured carbon emissions [Burling et al., 2011; Akagi et al., 2013]. Fuel carbon mass fraction $\left(F_{C}\right)$, on a dry mass of fuel basis, was measured for laboratory fuels (Table 2) based on the combustion method [Allen et al., 1974] and was assumed to be 50\% for unknown fuels burned during the subset of prescribed fires that did not have fuel measurements. The measured carbon content in fuels similar to those consumed in the fires sampled during the SLOBB and SCREAM airborne studies ranged from 48 to 55\% [McMeeking et al., 2009; Burling et al., 2011].

\section{Results and Discussion}

We grouped the prescribed fires and fuels burned in the laboratory by ecosystem type as listed in Table 2. The prescribed fires measured during SLOBB took place in maritime chaparral and Sierra Nevada montane ecosystems, and the prescribed fires measured during SCREAM all occurred in the southeastern U.S. coastal plain ecosystem. The fuels tested during FLAME-III included several species from these ecosystems, namely manzanita, chamise, and ceanothus (chaparral), ponderosa and lodgepole pine (montane), and gallberry, turkey oak, wire grass, and the pocosin composite sample (SE coastal plain). We also burned several fuels during FLAME-III from ecosystems not sampled with the aircraft. Note that for all FLAME-III experiments, we examined fire-integrated or fire-averaged emissions, rather than real-time emission data.

The fire-integrated MCE values observed over the duration of the burn during the FLAME-III laboratory measurements ranged between approximately 0.85 and 0.96 , reflecting the variability in combustion conditions from burn to burn. MCE values measured at various plume locations during the aircraft campaigns ranged from 0.89 to 0.95 during SLOBB and 0.92 to 0.97 during SCREAM. This variability between laboratory and aircraft measurements may be due to natural variability in MCE caused by fuel composition, moisture content, or loading, or due to laboratory measurements representing fire-integrated values (i.e., over all combustion phases). Further, Akagi et al. [2014] compared ground and airborne measurements of MCE during SCREAM and found that ground-level MCE was roughly $10 \%$ less than the airborne MCE; hence, the emissions aloft may be more influenced by flaming combustion. Nevertheless, we relied on the MCE to attempt to account for differences in combustion conditions when comparing aircraft and laboratory measurements of particle emissions in the following sections. MCE cannot, however, explain all of the variance in emissions, so there was residual variance due to the other factors listed above (e.g., fuel composition and fuel loading).

In the subsequent sections, we report emission ratios of $\triangle \mathrm{rBC}$ to $\triangle C O\left(\mathrm{ER}_{\mathrm{rBC}}\right)$ with units of ng rBC sm${ }^{-3}$ ppbv $\mathrm{CO}^{-1}$, following the standard convention in SP2 literature. However, we report emission ratios of other aerosol constituents on a mass basis (e.g., $\mathrm{ER}_{\mathrm{OA}}=\left[\mathrm{g} \mathrm{OA} \mathrm{gCO}^{-1}\right]$ ). To convert reported $\mathrm{ER}_{\mathrm{rBC}}$ to mass ratios, 
Table 3. Emission Ratios Measured for Aerosol Components During Individual Laboratory Burns and Prescribed Fires as Well as Averages by Ecosystem Types ${ }^{a}$

\begin{tabular}{|c|c|c|c|c|c|c|c|c|c|c|c|}
\hline Fuel/Fire & Type & MCE & $\begin{array}{l}\text { Fuel Moisture } \\
\text { (Dry wt \%) }\end{array}$ & $\begin{array}{c}\mathrm{rBC}\left(\mathrm{ng} \mathrm{sm}^{-3}\right. \\
\left.\mathrm{ppbv}^{-1}\right)\end{array}$ & $\begin{array}{c}\mathrm{OA} \\
\left(\mathrm{g} \mathrm{g}^{-1}\right)\end{array}$ & $\begin{array}{c}\mathrm{SO}_{4}{ }^{2-} \\
\left(\mathrm{mg} \mathrm{g}^{-1}\right)\end{array}$ & $\begin{array}{c}\mathrm{NO}_{3}^{-} \\
\left(\mathrm{mg} \mathrm{g}^{-1}\right)\end{array}$ & $\begin{array}{c}\mathrm{NH}_{4}^{+} \\
\left(\mathrm{mg} \mathrm{g}^{-1}\right)\end{array}$ & $\begin{array}{c}\mathrm{Chl}^{-} \\
\left(\mathrm{mg} \mathrm{g}^{-1}\right)\end{array}$ & $\begin{array}{l}\mathrm{PM}_{1} \\
\left(\mathrm{~g} \mathrm{~g}^{-1}\right)\end{array}$ & $\begin{array}{c}\mathrm{COA}_{\mathrm{OA}} \\
(\mu \mathrm{g} \mathrm{sm})^{-3} \mathrm{e}^{-}\end{array}$ \\
\hline \multicolumn{12}{|c|}{ Chaparral } \\
\hline Ceanothus & $\mathrm{L}$ & 0.942 & 9.9 & - & 0.048 & 3.0 & 0.8 & 0.1 & 1.7 & - & 945 \\
\hline Chamise & $\mathrm{L}$ & 0.943 & 10.0 & 22.1 & 0.008 & 3.7 & 0.2 & 0.0 & 0.6 & 0.04 & 72 \\
\hline Manzanita (54) & L & 0.956 & 11.1 & 25.2 & 0.015 & 1.0 & 0.4 & 0.1 & 1.4 & 0.04 & 120 \\
\hline Manzanita (60) & $\mathrm{L}$ & 0.956 & 8.4 & 26.8 & 0.013 & 2.1 & 0.3 & 0.1 & 1.0 & 0.05 & 115 \\
\hline Atmore fire ${ }^{c}$ & A & 0.947 & $n / a$ & 23.2 & 0.003 & - & - & - & 0.10 & 0.02 & 2.3 \\
\hline Grant A fire & A & 0.938 & $n / a$ & 27.9 & 0.033 & 0.19 & 0.59 & 0.36 & 1.7 & 0.06 & 88 \\
\hline Grant B fire & A & 0.903 & $n / a$ & 16.4 & 0.033 & 0.10 & 0.45 & 0.12 & 0.23 & 0.05 & 134 \\
\hline Williams fire & A & 0.933 & $n / a$ & 21.4 & 0.078 & 0.13 & 2.1 & 1.3 & 1.1 & 0.10 & 734 \\
\hline Laboratory average & $L$ & $0.949 \pm 0.008$ & $9.9 \pm 1.1$ & $24.7 \pm 2.4$ & $0.021 \pm 0.018$ & $2.5 \pm 1.2$ & $0.4 \pm 0.2$ & $0.07 \pm 0.03$ & $1.2 \pm 0.5^{\mathrm{d}}$ & $0.043 \pm 0.006$ & $313 \pm 421$ \\
\hline Aircraft average ${ }^{c^{c}}$ & $A$ & $0.924 \pm 0.019$ & $n / a$ & $21.9 \pm 5.8$ & $\begin{array}{r}0.048 \pm 0.026 \\
\text { Montane }\end{array}$ & $0.14 \pm 0.04$ & $1.05 \pm 0.92$ & $0.60 \pm 0.63$ & $1.01 \pm 0.74^{\mathrm{d}}$ & $0.070 \pm 0.026$ & $319 \pm 360$ \\
\hline Lodgepole pine (38) & L & 0.921 & 45.5 & 6.1 & 0.60 & 1.7 & 1.6 & 0.30 & 2.4 & 0.62 & 3160 \\
\hline Lodgepole pine (50) & L & 0.889 & 82.8 & 2.0 & 1.24 & 2.1 & 5.6 & 0.66 & 1.0 & 1.25 & 3490 \\
\hline Lodgepole pine (61) & L & 0.883 & 60.7 & 2.3 & 1.14 & 2.1 & 4.7 & 0.70 & 1.3 & 1.15 & 4980 \\
\hline Ponderosa pine (40) & L & 0.889 & 74.2 & 1.5 & 1.53 & 1.5 & 2.9 & 0.59 & 0.7 & 1.53 & 6710 \\
\hline Ponderosa pine (48) & L & 0.871 & 84.2 & - & 1.14 & 2.0 & 4.1 & 0.60 & 0.6 & - & 3620 \\
\hline Ponderosa pine (57) & L & 0.892 & 77.6 & 2.1 & 1.19 & 1.9 & 4.7 & 0.78 & 0.7 & 1.20 & 5770 \\
\hline Shaver fire & A & 0.885 & $n / a$ & 6.7 & 0.104 & 0.07 & 1.7 & 0.48 & 0.13 & 0.11 & 174 \\
\hline Turtle fire & A & 0.913 & $n / a$ & 6.3 & 0.095 & 0.07 & 1.8 & 0.67 & 0.13 & 0.10 & 195 \\
\hline Laboratory average & $L$ & $0.891 \pm 0.017$ & $70.8 \pm 14.9$ & $2.8 \pm 1.9$ & $1.14 \pm 0.30$ & $1.9 \pm 0.2$ & $3.9 \pm 1.5$ & $0.6 \pm 0.2$ & $1.1 \pm 0.7^{\mathrm{d}}$ & $1.15 \pm 0.33$ & $4620 \pm 1430$ \\
\hline Aircraft average & $A$ & $0.899 \pm 0.020$ & $n / a$ & $6.5 \pm 0.3$ & $0.10 \pm 0.01$ & $0.07 \pm 0.001$ & $1.7 \pm 0.06$ & $0.58 \pm 0.13$ & $0.13 \pm 0.001^{d}$ & $0.11 \pm 0.01$ & $185 \pm 15$ \\
\hline \multicolumn{12}{|c|}{ SE Coastal Plain } \\
\hline Gallberry (44) & L & 0.954 & 39.3 & 18.0 & 0.19 & 2.9 & 1.0 & 0.1 & 1.3 & 0.21 & 1490 \\
\hline Gallberry (47) & $\mathrm{L}$ & 0.947 & 63.3 & 18.9 & 0.29 & 1.7 & 1.2 & 0.1 & 0.9 & 0.31 & 1580 \\
\hline Pocosin (41) & L & 0.960 & 9.1 & 21.5 & 0.03 & 0.7 & 0.3 & 0.1 & 0.7 & 0.05 & 168 \\
\hline Pocosin (63) & $\mathrm{L}$ & 0.950 & 8.4 & 12.0 & 0.04 & 0.5 & 0.4 & 0.1 & 0.7 & 0.06 & 517 \\
\hline Turkey oak (45) & $\mathrm{L}$ & 0.947 & 11.4 & 19.5 & 0.02 & 1.0 & 0.3 & 0.5 & 2.9 & 0.05 & 177 \\
\hline Turkey oak (52) & $\mathrm{L}$ & 0.900 & 42.8 & 4.8 & 0.34 & 0.5 & 1.5 & 0.6 & 3.6 & 0.35 & 3770 \\
\hline Wire grass (42) & $\mathrm{L}$ & 0.969 & 29.4 & - & 0.07 & 0.8 & 0.3 & 2.1 & 14.8 & - & 380 \\
\hline Wire grass (56) & $\mathrm{L}$ & 0.959 & 12.1 & 16.0 & 0.20 & 0.8 & 1.3 & 1.4 & 11.1 & 0.23 & 869 \\
\hline FJ 6 fire & A & 0.932 & $n / a$ & 13.0 & - & - & - & - & - & - & - \\
\hline FJ 9a fire & A & 0.919 & $n / a$ & 8.2 & 0.026 & 1.0 & 0.43 & 0.37 & 0.14 & 0.035 & 904 \\
\hline FJ 22b fire & A & 0.935 & $n / a$ & 17.1 & 0.063 & 1.6 & 1.4 & 0.76 & 0.38 & 0.08 & 2200 \\
\hline Georgetown fire & A & 0.938 & $n / a$ & 21.8 & 0.028 & 1.3 & 1.5 & 1.5 & 5.4 & 0.06 & 266 \\
\hline Francis Marion fire & A & 0.933 & $n / a$ & 37.0 & 0.036 & 1.1 & 0.99 & 0.48 & 0.92 & 0.07 & 604 \\
\hline Bamberg A fire & A & 0.943 & $n / a$ & 16.7 & 0.047 & 4.5 & 2.0 & 1.6 & 0.53 & 0.07 & 393 \\
\hline Bamberg B fire & A & 0.973 & $n / a$ & 11.4 & 0.020 & 8.8 & 2.2 & 2.5 & 0.33 & 0.04 & 135 \\
\hline Laboratory average & $L$ & $0.948 \pm 0.021$ & $27.0 \pm 20.1$ & $15.8 \pm 5.7$ & $0.15 \pm 0.13$ & $1.1 \pm 0.8$ & $0.8 \pm 0.5$ & $0.6 \pm 0.8$ & $4.5 \pm 5.4^{d}$ & $0.18 \pm 0.13$ & $1120 \pm 1200$ \\
\hline Aircraft average & \multicolumn{10}{|c|}{ Boreal } & $750 \pm 760$ \\
\hline Alaskan duff & L & 0.900 & 19.2 & 0.5 & 0.12 & 0.3 & 0.8 & 0.2 & 0.1 & 0.12 & 832 \\
\hline Black spruce & L & 0.957 & 10.9 & 19.3 & 0.07 & 0.4 & 0.4 & 0.1 & 1.0 & 0.10 & 233 \\
\hline White spruce & L & 0.950 & 9.0 & 41.6 & 0.23 & 1.2 & 1.1 & 0.1 & 1.3 & 0.28 & 934 \\
\hline \multicolumn{12}{|c|}{$\begin{array}{r}0.14 \pm 0.08 \\
\text { Others }\end{array}$} \\
\hline Indonesian peat & $\mathrm{L}$ & 0.891 & 177.7 & 0.03 & 0.20 & 0.4 & 0.8 & 0.4 & 0.4 & 0.20 & 1110 \\
\hline Sagebrush (49) ${ }^{b}$ & L & 0.925 & 15.5 & 20.0 & 0.02 & 8.2 & 0.7 & 0.1 & 3.4 & 0.05 & 154 \\
\hline Sagebrush $(53)^{b}$ & L & 0.924 & 15.6 & 21.3 & 0.01 & 3.1 & 0.8 & 0.1 & 2.2 & 0.04 & 99 \\
\hline Saw grass $(43)^{b}$ & L & 0.958 & 10.8 & 28.0 & 0.06 & 1.6 & 0.4 & 2.3 & 14.2 & 0.11 & 326 \\
\hline Saw grass $(58)^{b}$ & L & 0.939 & 8.0 & 16.2 & 0.28 & 2.0 & 1.2 & 3.8 & 25.3 & 0.33 & 3044 \\
\hline Wheat straw & L & 0.913 & 9.0 & 5.7 & 0.02 & 1.5 & 0.2 & 0.0 & 0.6 & 0.03 & 350 \\
\hline
\end{tabular}

${ }^{2}$ Type indicates either laboratory measurements (L) or aircraft measurement (A). Numbers in parentheses indicate specific burn IDs in the case of repeated fuels during FLAME-III. Ecosystem averages are reported \pm 1 standard deviation. Units for $\mathrm{rBC}$ are presented based on standard convention; conversion to $\mathrm{g}$ rBC $\mathrm{g}$ CO ${ }^{-1}$ can be achieved via multiplication by a factor of $8.7 \times 10^{-4} . \mathrm{PM}_{1}$ refers to particulate matter with aerodynamic diameter less than $1 \mu \mathrm{m}$ as represented by the sum of $\mathrm{rBC}, \mathrm{OA}, \mathrm{SO}_{4}{ }^{2-}, \mathrm{NO}_{3}{ }^{-}, \mathrm{NH}_{4}{ }^{+}$, and $\mathrm{Chl}^{-}$. Airborne MCE is based on Fourier transform infrared measurements [Burling et al., 2011; Akagi et al., 2013], while laboratory MCE was calculated from gas analyzer measurements. Fuel moistures are repeated from Table 2 . Also provided are fire averaged (laboratory) and average plume-integrated (aircraft) OA mass concentrations $\left(\mathrm{C}_{\mathrm{OA}}\right)$.

${ }^{b}$ Sagebrush and saw grass may sometimes be classified as chaparral and SE coastal plain fuels, respectively.

Atmore fire data excluded from average values, as described in the text.

${ }^{d}$ Average of $\mathrm{PM}_{1}$, not sum of the average of the components. This value differs slightly from the sum of the averages due to the exclusion of certain components that were unavailable (e.g., $\mathrm{rBC}$ for ponderosa pine with burn ID $=48$ ).

${ }^{e_{F}}$ Fire-averaged OA mass concentration for laboratory measurements, average plume-integrated OA mass concentration for aircraft measurements. 


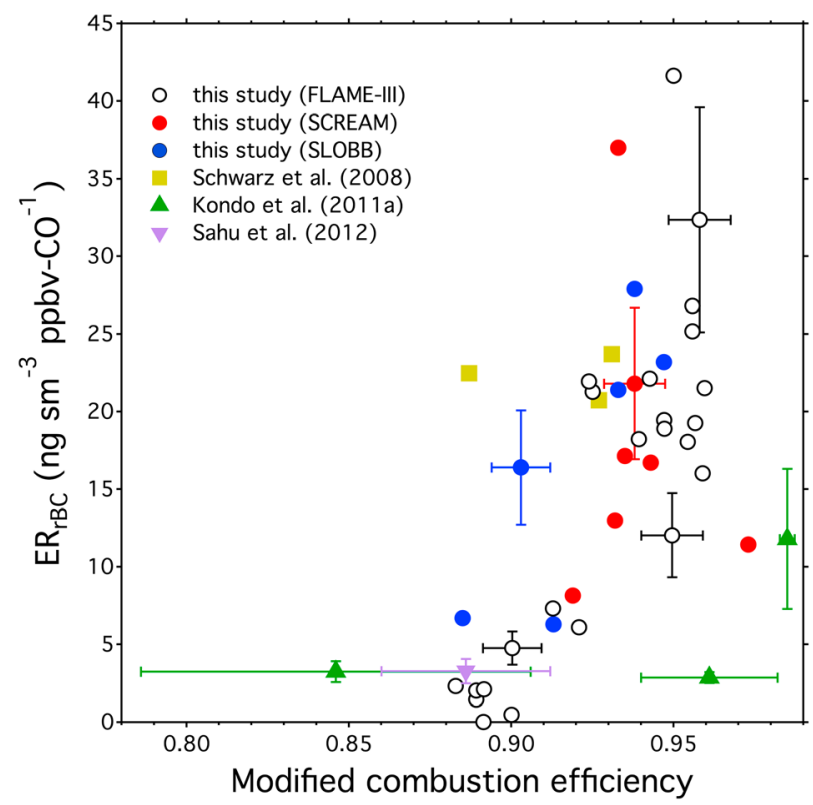

Figure 2. Fire-averaged $\mathrm{rBC}$ emission ratios as a function of modified combustion efficiency for the FLAME-III laboratory burns and for aircraft measurements over prescribed fires. Representative measurement uncertainties of $\pm 25 \%$ in rBC measurements, $2 \%$ in CO measurements, and $1 \%$ in $\mathrm{CO}_{2}$ measurements are propagated and shown for select data from our study. Published data for biomass burning plumes of varying atmospheric ages from Schwarz et al. [2008], Kondo et al. [2011 b], and Sahu et al. [2012] are shown for comparison; uncertainty bars represent 1 standard deviation, where available, for these data.

They ranged from approximately 0 to $40 \mathrm{ng} \mathrm{rBC} \mathrm{sm}^{-3} \mathrm{ppbv} \mathrm{CO}^{-1}$ and tended to be lowest for laboratory burns characterized by predominantly smoldering combustion and highest for laboratory burns dominated by flaming combustion. The chaparral fires had the highest average $\mathrm{ER}_{\mathrm{rBC}}$ values, with laboratory values of $24.7 \pm 2.4 \mathrm{ng} \mathrm{rBC} \mathrm{sm}^{-3} \mathrm{ppbv} \mathrm{CO}^{-1}$ and aircraft values of $21.9 \pm 5.8 \mathrm{ng} \mathrm{rBC} \mathrm{sm}^{-3} \mathrm{ppbv} \mathrm{CO}^{-1}$. We have excluded the Atmore fire from this, and subsequent, averages for chaparral fires as it was a very small ( $10 \mathrm{ha})$ coastal fire, and it was considered to be a statistical outlier, having an rBC-to-OA ratio that was roughly 23 standard deviations greater than the average for the other aircraft data (Grant A, Grant B, and Williams). The montane fuels had the lowest $\mathrm{ER}_{\mathrm{rBC}}$, emitting $2.8 \pm 1.9 \mathrm{ng} \mathrm{rBC} \mathrm{sm}^{-3} \mathrm{ppbv} \mathrm{CO}^{-1}$ in the laboratory and $6.5 \pm 0.3 \mathrm{ng} \mathrm{rBC} \mathrm{sm}^{-3} \mathrm{ppbv} \mathrm{CO}^{-1}$ during airborne sampling. Southeastern U.S. coastal plain fuels and fires had a laboratory-measured $\mathrm{ER}_{\mathrm{rBC}}$ of $15.8 \pm 5.7 \mathrm{ng} \mathrm{BC} \mathrm{sm}^{-3} \mathrm{ppbv} \mathrm{CO}^{-1}$ and an aircraft-measured $\mathrm{ER}_{\mathrm{rBC}}$ of $17.9 \pm 9.5 \mathrm{ng} \mathrm{rBC} \mathrm{sm}^{-3} \mathrm{ppbv} \mathrm{CO}^{-1}$. The relatively good agreement observed between laboratory- and aircraft-measured emissions of $\mathrm{rBC}$ from chaparral and SE coastal plain fires ( $p$ values $=0.453$ and 0.630 , respectively) provides some confidence in the representativeness of using the laboratory emission measurements to predict $\mathrm{rBC}$ emissions in the absence of field data. We note also that, within a fuel class, the MCE varied between laboratory and field data; for example, the average laboratory MCE for chaparral fuels was roughly 0.025 greater than the average MCE measured above chaparral prescribed fires. Since rBC emissions depend on MCE, we expect some variability due to this factor.

The aircraft-measured $\mathrm{ER}_{\mathrm{rBC}}$ for montane prescribed fires were roughly a factor of 2 higher than the laboratory measurements (Table 3), which is the largest discrepancy among all laboratory/field comparisons for $\mathrm{rBC}$ ( $p$ value $=0.046$ ), although we are only comparing six laboratory-derived values to two airbornederived values. Possible causes of this difference include, but may not be limited to, the following: (1) laboratory MCE for montane fuels was slightly lower than MCE measured in the aircraft for this ecosystem (0.891 versus 0.899 ); ( 2 ) only pine needles and branches were burned in the laboratory for montane ecosystem fuels, while shrub-layer species and downed dead wood were burned during the two prescribed 
fires; (3) the structure of the fuel bed in the laboratory is better maintained for shrubs and grasses compared to trees; and (4) emissions of OA were sometimes very high in the laboratory (see discussion in section 3.3 below), and the unidentified factors driving high OA may have also resulted in low rBC. For example, both Chen et al. [2010] and Hayashi et al. [2014] observe some decreases in EC emissions for fuels with increased moisture content. Hence, it is likely that the laboratory burns were not fully representative of the prescribed fires for these four reasons, although differences in fuels consumed and fuel moisture content (related to the fourth item in the list) may be most important. Conversely, chaparral and southeastern prescribed fires tended to burn grasses and shrubs that were also studied in the laboratory; average field and laboratory $\mathrm{ER}_{\mathrm{rBC}}$ for these fires agreed within 13\% (excluding Atmore) for chaparral and 12\% for southeastern prescribed fires (relative percent difference).

Refractory black carbon is emitted by flaming combustion, so we expected higher emissions from fires that had a larger MCE, as indicated in Figure 2. The relationship between $E_{r B C}$ and $M C E$ was generally consistent for both laboratory- and aircraft-measured fires, suggesting laboratory and prescribed fires produced similar amounts of $\mathrm{rBC}$ relative to $\mathrm{CO}$ for similar $\mathrm{MCE}$, despite all the differences between the conditions in the laboratory and the field. Hence, MCE appears to be a useful parameter for describing the variability in $E R_{r B C}$ measured for different fires, so intercomparisons of $E R_{r B C}$ from different studies should be accompanied by MCE as a diagnostic.

\subsection{2. rBC Emission Factors}

Emission factors for $\mathrm{rBC}\left(\mathrm{EF}_{\mathrm{rBC}}\right)$ for the laboratory and prescribed fire emissions are listed in Table 4 and shown as a function of MCE in Figure 3a. Laboratory fires had the largest range in $\mathrm{EF}_{\mathrm{rBC}}$, with some producing little measurable rBC above background concentrations and others emitting as much as $2.7 \mathrm{~g} \mathrm{rBC} \mathrm{kg} \mathrm{fuel}^{-1}$. Ecosystem-averaged $\mathrm{EF}_{\mathrm{rBC}}$ measured from the aircraft were $1.43 \pm 0.13 \mathrm{~g} \mathrm{~kg} \mathrm{fuel}^{-1}$ for chaparral (excluding Atmore), $0.59 \pm 0.13 \mathrm{~g} \mathrm{~kg} \mathrm{fuel}^{-1}$ for montane, and $1.11 \pm 0.67 \mathrm{~g} \mathrm{~kg} \mathrm{fuel}^{-1}$ for SE coastal plain prescribed fires. Emission factors had a similar relationship with $\mathrm{MCE}$ as was observed for $\mathrm{ER}_{\mathrm{rBC}}$, again reflecting the role of flaming combustion in the production of $\mathrm{rBC}$; however, the coefficient of determination $\left(R^{2}\right)$ value of a global linear regression of these data was only 0.265 , suggesting that other factors likely affect the variability in the emission factors.

\subsubsection{Comparison to Prior Measurements}

There are few studies that have used the SP2 to measure rBC emissions from fires or from prescribed fires specifically. Kondo et al. [2011b] measured rBC with an SP2 in a number of smoke plumes over North America, as summarized in Figure 2. They report average $\mathrm{ER}_{\mathrm{rBC}}$ values of $11.8 \pm 4.5 \mathrm{ng} \mathrm{rBC} \mathrm{sm}^{-3} \mathrm{ppbv} \mathrm{CO}^{-1}$ for plumes originating in Asia (MCE $=0.985 \pm 0.002), 3.25 \pm 0.678 \mathrm{ng} \mathrm{rBC} \mathrm{sm}^{-3} \mathrm{ppbv} \mathrm{CO}^{-1}$ for plumes originating in Canada $(\mathrm{MCE}=0.846 \pm 0.060)$, and $2.86 \pm 0.35 \mathrm{ng} \mathrm{rBC} \mathrm{sm}^{-3} \mathrm{ppbv} \mathrm{CO}^{-1}$ for plumes originating in California $(\mathrm{MCE}=0.961 \pm 0.021)$. MCE calculated from excess $\mathrm{CO}_{2}$ and $\mathrm{CO}$ for highly aged and dilute plumes (e.g., Asian plumes sampled over North America) is more uncertain compared to measurements near the source where $\mathrm{CO}$ and $\mathrm{CO}_{2}$ are highly elevated above background levels [Yokelson et al., 2013b]. If the calculated MCE was too large due to uncertainties with long-range transport (e.g., as $\Delta \mathrm{CO}_{2}$ and $\Delta \mathrm{CO}$ approach zero, and hence, excess signal-to-noise decreases), this may potentially explain the discrepancy between the Kondo et al. [2011b] $\mathrm{ER}_{\mathrm{rBC}}$ measurements and our observations. The only other aircraft-based rBC measurements of which we are aware were made by Schwarz et al. [2008], who intercepted two smoke plumes over Texas they attributed to brush fires, Sahu et al. [2012], who sampled fire plumes over California, and Dahlkötter et al. [2014], who detected biomass burning plumes transported from North America over Europe. Schwarz et al. [2008] observed an $\mathrm{ER}_{\mathrm{rBC}}$ of $22.3 \pm 1.5 \mathrm{ng} \mathrm{BC} \mathrm{sm}^{-3} \mathrm{ppbv} \mathrm{CO}^{-1}$ averaged over three plume intercepts, similar to our observations over California chaparral fires, while Sahu et al. [2012] observed much lower $\mathrm{ER}_{\mathrm{rBC}}$ of $3.28 \pm 0.97 \mathrm{ng} \mathrm{rBC} \mathrm{sm}^{-3} \mathrm{ppbv} \mathrm{CO}^{-1}$. The data from these previous studies have also been included in Figure 2 and compare reasonably well to our data when the effects of MCE are considered; Dahlkötter et al. [2014] do not report $\mathrm{ER}_{\mathrm{rBC}}$ in their work. As a point of reference, urban/fossil fuel $\mathrm{ER}_{\mathrm{rBC}}$ reported in the literature range from roughly 1.5 to $7 \mathrm{ng} \mathrm{rBC} \mathrm{sm}^{-3} \mathrm{ppbv} \mathrm{CO}^{-1}$ [Baumgardner et al., 2007; Schwarz et al., 2008; McMeeking et al., 2010; Subramanian et al., 2010; Sahu et al., 2012].

Emission ratios measured for aged emissions may also be influenced by the removal of $B C$ from the smoke plume due to wet and dry deposition processes. Both our study and the Schwarz et al. [2008] measurements were restricted to emissions sampled within an hour of emission. The Kondo et al. [2011b] observations 
Table 4. Emission Factors Measured for Aerosol Components During Individual Laboratory Burns and Prescribed Fires as Well as Averages ${ }^{a}$

\begin{tabular}{|c|c|c|c|c|c|c|c|c|c|c|c|}
\hline Fire/Fuel & Type & MCE & $\begin{array}{l}\text { Fuel Moisture } \\
\text { (Dry wt. \%) }\end{array}$ & $\mathrm{rBC}$ & OA & $\mathrm{SO}_{4}{ }^{2-}$ & $\mathrm{NO}_{3}{ }^{-}$ & $\mathrm{NH}_{4}^{+}$ & $\mathrm{Chl}^{-}$ & $\mathrm{PM}_{1}$ & $\begin{array}{c}\mathrm{COA}_{\mathrm{OA}} \\
\left(\mu \mathrm{g} \mathrm{sm}^{-3}\right)^{\mathrm{e}}\end{array}$ \\
\hline \multicolumn{12}{|c|}{ Chaparral } \\
\hline Ceanothus & L & 0.942 & 9.9 & - & 3.4 & 0.22 & 0.05 & 0.00 & 0.12 & - & 945 \\
\hline Chamise & L & 0.943 & 10.0 & 1.73 & 0.6 & 0.28 & 0.02 & 0.00 & 0.05 & 2.7 & 72 \\
\hline Manzanita (54) & L & 0.956 & 11.1 & 1.49 & 0.8 & 0.06 & 0.02 & 0.00 & 0.08 & 2.5 & 120 \\
\hline Manzanita (60) & L & 0.956 & 8.4 & 1.59 & 0.7 & 0.11 & 0.02 & 0.01 & 0.05 & 2.5 & 115 \\
\hline Atmore fire $^{c}$ & $A$ & 0.947 & $n / a$ & 1.13 & 0.2 & - & - & - & 0.01 & 1.3 & 2.3 \\
\hline Grant A fire & $A$ & 0.938 & $n / a$ & 1.56 & 2.3 & 0.01 & 0.04 & 0.03 & 0.12 & 4.1 & 88 \\
\hline Grant B fire & $A$ & 0.903 & $n / a$ & 1.43 & 3.6 & 0.01 & 0.05 & 0.01 & 0.03 & 5.1 & 134 \\
\hline Williams fire & A & 0.933 & $n / a$ & 1.30 & 5.9 & 0.01 & 0.16 & 0.10 & 0.08 & 7.4 & 734 \\
\hline Laboratory average & $L$ & $0.949 \pm 0.008$ & $9.9 \pm 1.1$ & $1.60 \pm 0.12$ & $1.4 \pm 1.3$ & $0.17 \pm 0.10$ & $0.03 \pm 0.02$ & $0.00 \pm 0.00$ & $0.07 \pm 0.03$ & $2.6 \pm 0.1^{\mathrm{d}}$ & $313 \pm 421$ \\
\hline Aircraft average $e^{c^{3}}$ & $A$ & $0.925 \pm 0.019$ & $n / a$ & $1.43 \pm 0.13$ & $\begin{array}{l}3.9 \pm 1.8 \\
\text { Montan }\end{array}$ & $e^{0.01 \pm 0.01}$ & $0.08 \pm 0.07$ & $0.05 \pm 0.05$ & $0.08 \pm 0.05$ & $5.5 \pm 1.7$ & $319 \pm 360$ \\
\hline Lodgepole pine (38) & L & 0.921 & 45.5 & 0.65 & 65.3 & 0.18 & 0.17 & 0.03 & 0.26 & 66.5 & 3160 \\
\hline Lodgepole pine (50) & L & 0.889 & 82.8 & 0.30 & 184.4 & 0.25 & 0.67 & 0.09 & 0.14 & 185.9 & 3490 \\
\hline Lodgepole pine (61) & L & 0.883 & 60.7 & 0.36 & 168.9 & 0.31 & 0.70 & 0.10 & 0.19 & 170.5 & 4980 \\
\hline Ponderosa pine (40) & L & 0.889 & 74.2 & 0.22 & 218.1 & 0.21 & 0.41 & 0.08 & 0.10 & 219.1 & 6710 \\
\hline Ponderosa pine (48) & L & 0.871 & 84.2 & - & 189.4 & 0.34 & 0.69 & 0.10 & 0.10 & - & 3620 \\
\hline Ponderosa pine (57) & L & 0.892 & 77.6 & 0.31 & 191.9 & 0.30 & 0.76 & 0.11 & 0.11 & 193.5 & 5770 \\
\hline Shaver fire & $A$ & 0.885 & $n / a$ & 0.68 & 13.2 & 0.01 & 0.2 & 0.06 & 0.02 & 14.1 & 174 \\
\hline Turtle fire & A & 0.913 & $n / a$ & 0.49 & 9.3 & 0.01 & 0.2 & 0.07 & 0.01 & 10.0 & 195 \\
\hline Laboratory average & $L$ & $0.891 \pm 0.017$ & $70.8 \pm 14.9$ & $0.37 \pm 0.16$ & $169.7 \pm 53.6$ & $0.26 \pm 0.06$ & $0.57 \pm 0.23$ & $0.09 \pm 0.03$ & $0.15 \pm 0.06$ & $167.1 \pm 58.9^{\mathrm{d}}$ & $4620 \pm 1430$ \\
\hline \multicolumn{12}{|c|}{ SE Coastal Plain } \\
\hline Gallberry (44) & L & 0.954 & 39.3 & 1.13 & 11.2 & 0.18 & 0.06 & 0.01 & 0.08 & 12.7 & 1490 \\
\hline Gallberry (47) & L & 0.947 & 63.3 & 1.37 & 21.1 & 0.13 & 0.09 & 0.01 & 0.06 & 22.7 & 1580 \\
\hline Pocosin (41) & L & 0.960 & 9.1 & 1.17 & 1.5 & 0.04 & 0.02 & 0.00 & 0.04 & 2.8 & 168 \\
\hline Pocosin (63) & L & 0.950 & 8.4 & 0.82 & 2.8 & 0.03 & 0.02 & 0.01 & 0.05 & 3.7 & 517 \\
\hline Turkey oak (45) & L & 0.947 & 11.4 & 1.33 & 1.6 & 0.07 & 0.02 & 0.03 & 0.21 & 3.2 & 177 \\
\hline Turkey oak (52) & $\mathrm{L}$ & 0.900 & 42.8 & 0.62 & 41.3 & 0.06 & 0.18 & 0.08 & 0.44 & 42.7 & 3770 \\
\hline Wire grass (42) & $\mathrm{L}$ & 0.969 & 29.4 & - & 2.9 & 0.04 & 0.01 & 0.09 & 0.63 & - & 380 \\
\hline Wire grass (56) & L & 0.959 & 12.1 & 0.83 & 9.6 & 0.04 & 0.06 & 0.07 & 0.54 & 11.1 & 869 \\
\hline FJ 6 fire & $A$ & 0.932 & $n / a$ & 0.81 & - & - & - & - & - & - & - \\
\hline FJ 9a fire & $A$ & 0.919 & $n / a$ & 0.68 & 2.54 & 0.10 & 0.04 & 0.04 & 0.01 & 3.42 & 904 \\
\hline FJ 22b fire & $A$ & 0.935 & $n / a$ & 1.29 & 5.66 & 0.15 & 0.12 & 0.07 & 0.03 & 7.32 & 2200 \\
\hline Georgetown fire & $A$ & 0.938 & $n / a$ & 1.36 & 2.09 & 0.09 & 0.11 & 0.11 & 0.40 & 4.16 & 266 \\
\hline Francis Marion fire & $A$ & 0.933 & $n / a$ & 2.40 & 2.82 & 0.09 & 0.08 & 0.04 & 0.07 & 5.49 & 604 \\
\hline Bamberg A fire & $A$ & 0.943 & $n / a$ & 0.94 & 3.12 & 0.30 & 0.13 & 0.10 & 0.04 & 4.63 & 393 \\
\hline Bamberg B fire & $A$ & 0.973 & $n / a$ & 0.31 & 0.64 & 0.28 & 0.07 & 0.08 & 0.01 & 1.40 & 135 \\
\hline Laboratory average & $L$ & $0.948 \pm 0.021$ & $27.0 \pm 20.1$ & $1.04 \pm 0.29$ & $11.5 \pm 13.8$ & $0.07 \pm 0.05$ & $0.06 \pm 0.05$ & $0.04 \pm 0.04$ & $0.26 \pm 0.24$ & $14.1 \pm 14.5^{d}$ & $1120 \pm 1200$ \\
\hline Aircraft average & $A$ & $0.936 \pm 0.014$ & $n / a$ & $1.11 \pm 0.67$ & $\begin{array}{r}2.8 \pm 1.6 \\
\text { Boreal }\end{array}$ & $0.17 \pm 0.10$ & $0.09 \pm 0.03$ & $0.07 \pm 0.03$ & $0.09 \pm 0.15$ & $4.4 \pm 2.0$ & $750 \pm 760$ \\
\hline Alaskan duff & L & 0.900 & 19.2 & 0.06 & 27.5 & 0.06 & 0.17 & 0.05 & 0.03 & 27.9 & 832 \\
\hline Black spruce & L & 0.957 & 10.9 & 1.11 & 4.1 & 0.02 & 0.02 & 0.01 & 0.05 & 5.3 & 233 \\
\hline White spruce & L & 0.950 & 9.0 & 2.72 & 14.3 & 0.08 & 0.07 & 0.00 & 0.08 & 17.3 & 934 \\
\hline \multicolumn{12}{|c|}{ Others } \\
\hline Indonesian peat & L & 0.891 & 177.7 & 0.01 & 34.5 & 0.07 & 0.16 & 0.07 & 0.07 & 34.9 & 1110 \\
\hline Sagebrush $(49)^{\mathrm{b}}$ & $\mathrm{L}$ & 0.925 & 15.5 & 2.02 & 1.7 & 0.74 & 0.06 & 0.01 & 0.30 & 4.9 & 154 \\
\hline Sagebrush $(53)^{b}$ & $\mathrm{~L}$ & 0.924 & 15.6 & 2.12 & 1.1 & 0.28 & 0.07 & 0.01 & 0.20 & 3.8 & 99 \\
\hline Saw grass $(43)^{b}$ & $\mathrm{~L}$ & 0.958 & 10.8 & 1.70 & 2.9 & 0.08 & 0.02 & 0.12 & 0.73 & 5.6 & 326 \\
\hline Saw grass $(58)^{b}$ & L & 0.939 & 8.0 & 1.38 & 20.3 & 0.14 & 0.08 & 0.28 & 1.81 & 24.0 & 3044 \\
\hline Wheat straw & L & 0.913 & 9.0 & 0.74 & 2.1 & 0.14 & 0.02 & 0.00 & 0.05 & 3.0 & 350 \\
\hline
\end{tabular}

\footnotetext{
${ }^{\mathrm{a}}$ Type indicates either laboratory measurements (L) or aircraft measurement (A). Aircraft measurements are restricted to values near the source and do not account for changes in the emission factor due to dilution. Numbers in parentheses indicate specific burn IDs in the case of repeated fuels during FLAME-III. Ecosystem averages are reported \pm 1 standard deviation. Units for all components are $\mathrm{g} \mathrm{kg}$ dry-fuel consumed ${ }^{-1}$. $\mathrm{PM}_{1}$ refers to particulate matter with aerodynamic diameter less than $1 \mu \mathrm{m}$ as represented by the sum of $\mathrm{rBC}, \mathrm{OA}, \mathrm{SO}_{4}{ }^{2-}, \mathrm{NO}_{3}{ }^{-}, \mathrm{NH}_{4}{ }^{+}$, and $\mathrm{Chl}^{-}$. Fuel moisture is repeated from Table 2 while MCE and $\mathrm{COA}_{\mathrm{OA}}$ are repeated from Table 3.

${ }^{\mathrm{b}}$ Sagebrush and saw grass may sometimes be classified as chaparral and SE coastal plain fuels, respectively.

CAtmore fire data excluded from average values, as described in the text.

${ }^{d}$ Average of $\mathrm{PM}_{1}$, not sum of the average of the components. This value differs slightly from the sum of the averages due to the exclusion of certain components that were unavailable (e.g., $\mathrm{rBC}$ for ponderosa pine with burn ID=48).

${ }^{\mathrm{e}}$ Fire-averaged OA mass concentration for laboratory measurements, average plume-integrated OA mass concentration for aircraft measurements.
} 


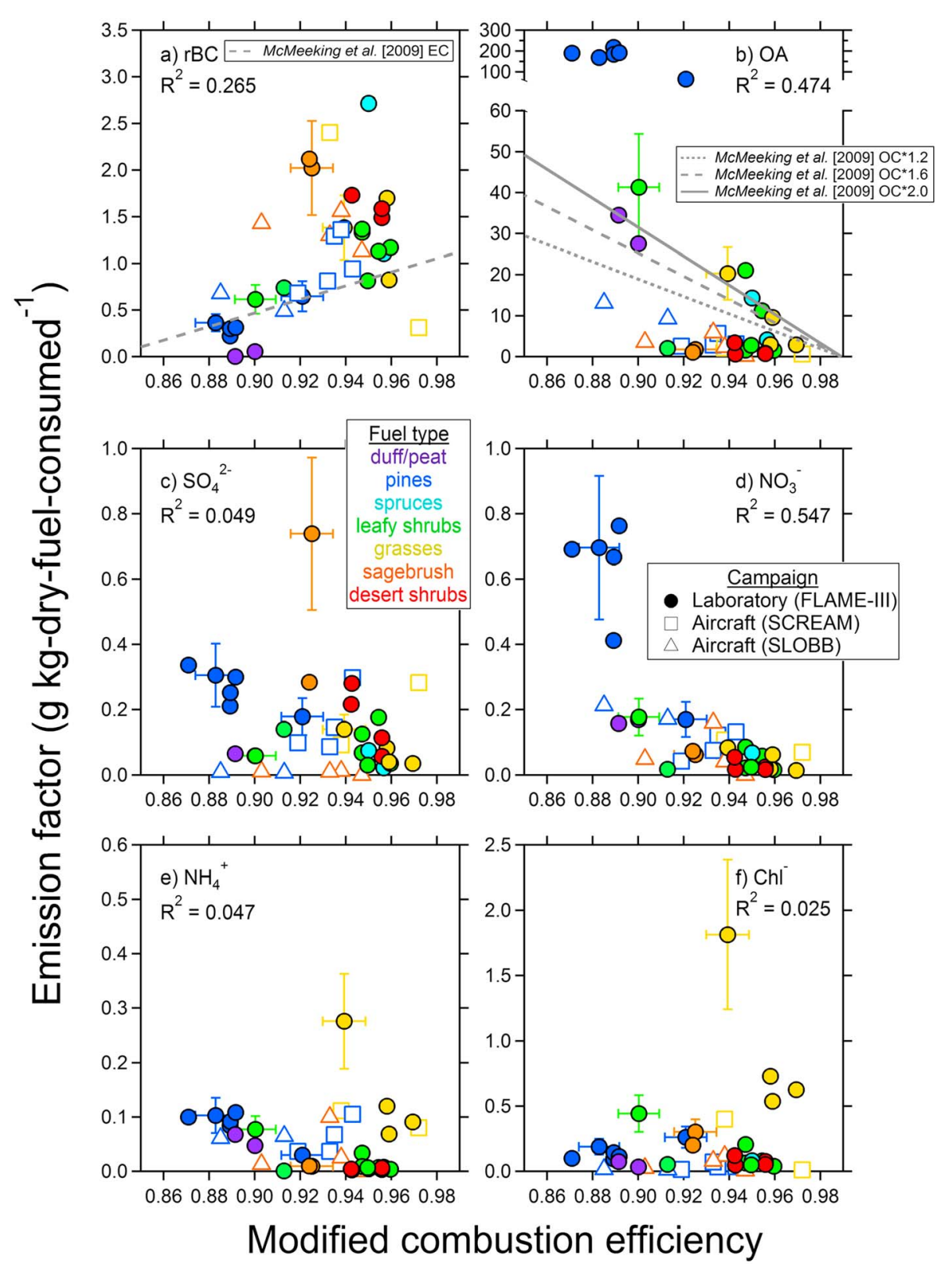

Figure 3. Emission factors measured for (a) refractory black carbon (rBC) compared to EC from McMeeking et al. [2009]; (b) organic aerosol (OA) compared to the fit for OC from McMeeking et al. [2009] multiplied by factors of 1.2, 1.6, and 2.0 (see text for details); (c) nitrate $\left(\mathrm{NO}_{3}{ }^{-}\right)$; (d) sulfate $\left(\mathrm{SO}_{4}{ }^{2-}\right) ;(\mathrm{e})$ ammonium $\left(\mathrm{NH}_{4}{ }^{+}\right)$; and (f) chloride $\left(\mathrm{Chl}^{-}\right)$in the laboratory (FLAME-III) and over prescribed fires by aircraft during the SLOBB (California) and SCREAM (South Carolina) campaigns. Points are colored according to approximate fuel classification. Representative measurement uncertainties of $\pm 30 \%$ in AMS measurements, $\pm 25 \%$ in rBC measurements, $2 \%$ in $\mathrm{CO}$ measurements, and $1 \%$ in $\mathrm{CO}_{2}$ measurements are propagated and provided for select data from this study. Coefficients of determination derived from global linear regressions of each species are also provided.

included much older smoke plumes, but they also restricted their analysis to samples that had minimal influence from precipitation based on an analysis of backward trajectories. Sahu et al. [2012] do not report sample age, but they sampled biomass burning emissions from wildfires in California during a flight campaign over California, restricting their data to those with excess acetonitrile (a gas-phase tracer for biomass burning) greater than 300 pptv. Possible reasons for differences between the aged plumes in previous work and our measurements of young plumes include the previously discussed higher uncertainty in determining MCE from small $\Delta \mathrm{CO}_{2}$ values relative to background $\mathrm{CO}_{2}$ in more aged plumes and 
differences in fuels or fire size (small prescribed fires versus large wildfires). The first possibility is supported by the fact that the $E R_{r B C}$ reported by both studies overlapped, but MCE did not.

Most previous measurements used to derive emission factors or emission ratios for BC from fire relied on filter-based optical or thermal-optical methods to quantify BC and have been summarized in several reviews [Andreae and Merlet, 2001; Bond et al., 2004, 2013; Akagi et al., 2011]. The classic review of Andreae and Merlet [2001] recommended a literature-averaged $\mathrm{EF}_{\mathrm{BC}}$ of $0.56 \pm 0.19 \mathrm{~g} \mathrm{~kg} \mathrm{fuel}^{-1}$ for extratropical forests, which is commonly used in emission inventories and chemical transport models [van der Werf et al., 2010; Akagi et al., 2011]. Many of our laboratory- and aircraft-measured emission factors for rBC from biomass burning were greater than 1 standard deviation above the recommended average from Andreae and Merlet [2001], especially for chaparral and SE coastal plain fuels (see Table 4); however, this value from Andreae and Merlet [2001] includes emissions from boreal fires, which we expect to be similar to our montane fires. Comparing $\mathrm{EF}_{\mathrm{rBC}}$ to emission factors of $\mathrm{EC}\left(\mathrm{EF}_{\mathrm{EC}}\right)$ from McMeeking et al. [2009], who studied similar ecosystems/fuels as the present work, $\mathrm{EF}_{\mathrm{rBC}}$ from the present study are generally greater than $\mathrm{EF}_{\mathrm{EC}}$ by roughly a factor of 1.5-3.0, as shown in Figure 3a. Similarly, for on-road motor vehicles, Liggio et al. [2012] propose that BC is underestimated in existing emission inventories for mobile sources, based on comparisons of their SP2 measurements and previous filter-based measurements. We speculate that, in general, this discrepancy may be related to an overcorrection for OC pyrolysis in OC/EC analysis methods rather than errors in the photoabsorption methods for determining BC; however, we lack systematic comparisons between methods for biomass burning samples during our study. We emphasize that $B C$ and $E C$ are both operationally defined and are not necessarily equivalent. The only systematic intercomparisons of differences between EC/BC measurement techniques of which we are aware are the following: Watson et al. [2005], who review prior EC/BC studies that demonstrate differences in mass concentrations up to a factor of 7; Kondo et al. [2011a], who demonstrate good agreement between different methods, although this finding is sensitive to their inferred BC mass absorption cross section; and Yelverton et al. [2014], who demonstrate that measured EC/BC mass concentrations measured via different instruments may vary up to a factor of 2 . Our results, in conjunction with previous work and regardless of the reason (e.g., systematic differences between instruments/analyses, larger available data set with greater natural variability), suggest that $\mathrm{EF}_{\mathrm{BC}}$ may require further upward revision in emission inventories, although additional measurements, particularly for wildfires, are needed to confirm this hypothesis. This statement is consistent with the upper uncertainty bound for BC proposed by Bond et al. [2013], who estimate that $\mathrm{EF}_{\mathrm{BC}}$ currently used in emission inventories may be biased low by up to a factor of 4 .

\subsection{Refractory Black Carbon Mass-Median Diameters}

Sizing information is critical to accurately predict aerosol microphysical and optical properties in models. Here we report the $M M D_{r B C}$ (described in section 2.2) for both laboratory and aircraft measurements. We calculated fire-averaged $\mathrm{MMD}_{\mathrm{rBC}}$ for all plumes intercepted within $5 \mathrm{~km}$ of the fire location to restrict our analysis of aircraft data to relatively fresh emissions. During the FLAME-III laboratory burns, we used the average $M_{M B C}$ observed during the same time period used to determine emission ratios and emission factors near the beginning of each experiment.

Laboratory-measured $\mathrm{MMD}_{\mathrm{rBC}}$ ranged between 0.14 and $0.19 \mu \mathrm{m}$, with the exception of that measured for emissions from Alaskan duff, which had an $\mathrm{MMD}_{\mathrm{rBC}}$ of $0.12 \mu \mathrm{m}$. The Alaskan duff burn emitted very little $\mathrm{rBC}$ and was the only laboratory burn where it was difficult to distinguish between the background $\mathrm{rBC}$ and the $\mathrm{rBC}$ emitted by the fire, so we excluded this fuel from the following analyses. The average $\mathrm{MMD}_{\mathrm{rBC}}$ of all fuels,

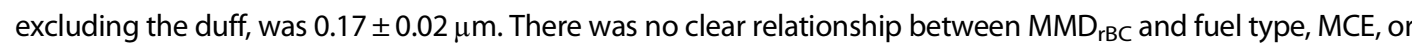
total $\mathrm{rBC}$ mass emitted. Refractory BC MMD shifted to larger particle sizes in emissions from the coastal plain prescribed fires measured over South Carolina during SCREAM, with a campaign average $\pm 1 \sigma$ of $0.22 \pm 0.01 \mu \mathrm{m}$. These aircraft-measured $\mathrm{MMD}_{\mathrm{rBC}}$ were roughly $30 \%$ larger than those measured in the laboratory (average laboratory SE coastal plain fuel $\mathrm{MMD}_{\mathrm{rBC}}=0.17 \pm 0.01 \mu \mathrm{m}$ ) but were consistent with previous SP2 measurements of biomass burning rBC. For example, Schwarz et al. [2008] observed a $\mathrm{MMD}_{\mathrm{rBC}}$ of $0.21 \mu \mathrm{m}$ for the biomass burning plume encountered over Texas. Kondo et al. [2011b] observed $\mathrm{MMD}_{\mathrm{rBC}}$ values of $0.21 \mu \mathrm{m}$ and $0.19 \mu \mathrm{m}$ for biomass burning emissions from Asia and Canada, respectively, while Sahu et al. [2012] reported average $\mathrm{MMD}_{\mathrm{rBC}}$ of $0.20 \pm 0.02 \mu \mathrm{m}$. Both Kondo et al. [2011b] and Sahu et al. [2012] values have been adjusted using our 
assumed rBC density of $1.8 \mathrm{~g} \mathrm{~cm}^{-3}$. Conversely, Dahlkötter et al. [2014] reported a range of $\mathrm{MMD}_{\mathrm{rBC}}$ from 0.12 to $0.15 \mu \mathrm{m}$ for a smoke plume that had undergone long-range transport from North America to Europe; these $\mathrm{MMD}_{\mathrm{rBC}}$ are more similar to our laboratory studies, but the exact cause of the difference between these measurements and other plume measurements is unknown. Nevertheless, the comparison of our results with prior work highlights the variability in $\mathrm{MMD}_{\mathrm{rBC}}$, which can bound aerosol microphysical and optical processes in predictive model simulations.

\subsection{Nonrefractory Aerosol Emissions}

\subsubsection{Emission Ratios}

The emission ratios for the major AMS-measured nonrefractory submicron aerosol components are listed in Table 3. Figure 4 shows an example of the regressions used to determine the emission ratios for nonrefractory aerosol (as well as rBC) during the Fort Jackson plot 22b prescribed fire (2 November 2011). Each point represents a single plume interception that was measured during the flight and that was confirmed as a plume hit via a spike in CRDS CO within $5 \mathrm{~km}$ of the fire location. An ordinary least squares regression, forcing the intercept through zero, was used to derive the slope best representing the data, with this slope used to infer the ER [Yokelson et al., 1999]; we expect the intercept to be zero since all values are backgroundcorrected locally. In the laboratory, background OA concentrations were generally $<5 \mu \mathrm{g} \mathrm{m}^{-3}$, while in the field, background $O A$ concentrations range from roughly 5 to $15 \mu \mathrm{g} \mathrm{m}^{-3}$. Observed emission ratios for organic aerosol ( $\left.\mathrm{ER}_{\mathrm{OA}}\right)$ were generally higher during montane prescribed fires than during SE coastal plain fires and chaparral fires, with average values of $0.10 \pm 0.01 \mathrm{~g} \mathrm{OA} \mathrm{g} \mathrm{CO}^{-1}$. We observed lower average values of $0.037 \pm 0.016 \mathrm{~g} \mathrm{OA} \mathrm{g} \mathrm{CO}^{-1}$ over SE coastal fires and $0.048 \pm 0.026 \mathrm{~g} \mathrm{OA} \mathrm{g} \mathrm{CO}^{-1}$ over chaparral fires (excluding Atmore). Cubison et al. [2011] summarized recent measurements of $\mathrm{ER}_{\mathrm{OA}}$ and concluded that $\mathrm{ER}_{\mathrm{OA}}$ can range from approximately 0.04 to $0.15 \mathrm{~g} \mathrm{OA} \mathrm{g} \mathrm{CO}^{-1}$ for nonaged emissions, while Jolleys et al. [2012] report a larger range of $\mathrm{ER}_{\mathrm{OA}}$ of $0.02-0.33 \mathrm{~g} \mathrm{OA} \mathrm{g} \mathrm{CO}^{-1}$ for various aircraft campaigns, both being consistent with the range of values we observed over our prescribed fires.

Laboratory-measured $\mathrm{ER}_{\mathrm{OA}}$ represented a much larger range of values compared to the aircraft measurements, ranging from $0.021 \pm 0.018 \mathrm{~g} \mathrm{OA} \mathrm{g} \mathrm{CO}^{-1}$ for chaparral species to $0.15 \pm 0.13 \mathrm{~g} \mathrm{OA} \mathrm{g} \mathrm{CO}^{-1}$ for $\mathrm{SE}$ coastal plain species to $1.14 \pm 0.30 \mathrm{~g} \mathrm{OA} \mathrm{g} \mathrm{CO}^{-1}$ for montane species. Laboratory and airborne ER $\mathrm{OA}_{\mathrm{OA}}$ from chaparral fires differ by roughly a factor of 2; this could potentially be related to the assumed AMS CE for the field data. However, an unpaired $t$ test (excluding the Atmore fire as described above) suggests that this difference is not statistically significant (two-tailed $p$ value $=0.164$ ).

The values for montane fuels are well over 10 times our aircraft observations and reported literature values for extratropical/pine understory forests [Akagi et al., 2011; Yokelson et al., 2013a], which is a statistically significant difference ( $p$ value $=0.0036$ ). We attribute the factor of 5-10 difference between airborne and laboratoryderived $\mathrm{ER}_{\mathrm{OA}}$ for montane and SE coastal plain fuels ( $p$ value $\left.=0.054\right)$ to $(a)$ high-fuel moisture content and $(b)$ gas-to-particle partitioning of semivolatile material at high OA mass concentrations, similar to May et al. [2013]; assumed values of AMS CE may also play a role, but neither can wholly explain these differences. During FLAME-III, initial fuel moisture contents relative to dry fuel mass prior to fuel conditioning ranged from roughly 45 to $75 \%$ for lodgepole and ponderosa pines; both Chen et al. [2010] and Hayashi et al. [2014] observed that OC emissions and fuel moisture content were positively correlated, suggesting that laboratory-derived emission factors may be biased high partly due to preignition pyrolysis emissions of OA in the presence of high-fuel moisture. We expect the moisture content of the fine dead fuels during the Turtle and Shaver burns to be roughly $10 \%$, as targeted in the Turtle burn plan, which is roughly a factor of 7 lower than in the laboratory; furthermore, nearby meteorological stations indicated that neither site received any precipitation in the 17 days preceding the prescribed fire. Similarly, laboratory SE coastal plain fuels with moisture contents of roughly $10 \%$ were generally consistent with our airborne observations, while those laboratory fuels with greater fuel moisture contents were generally larger than our airborne observations. Hence, high residual water in the fuel prior to combustion may explain the very large $\mathrm{ER}_{\mathrm{OA}}$ for montane fuels in our study.

However, our observations may also be biased by the fact that primary OA emitted from fires has been observed to be semivolatile, and thus, will vary nonlinearly with dilution [Lipsky and Robinson, 2006; Grieshop et al., 2009a; Huffman et al., 2009; May et al., 2013]; that is, higher OA concentrations will draw additional semivolatile organic vapors into the particle phase in order to maintain thermodynamic equilibrium [Donahue et al., 2006; Robinson et al., 2010]. Laboratory fires that produced the highest $\mathrm{ER}_{\mathrm{OA}}$ also had the 

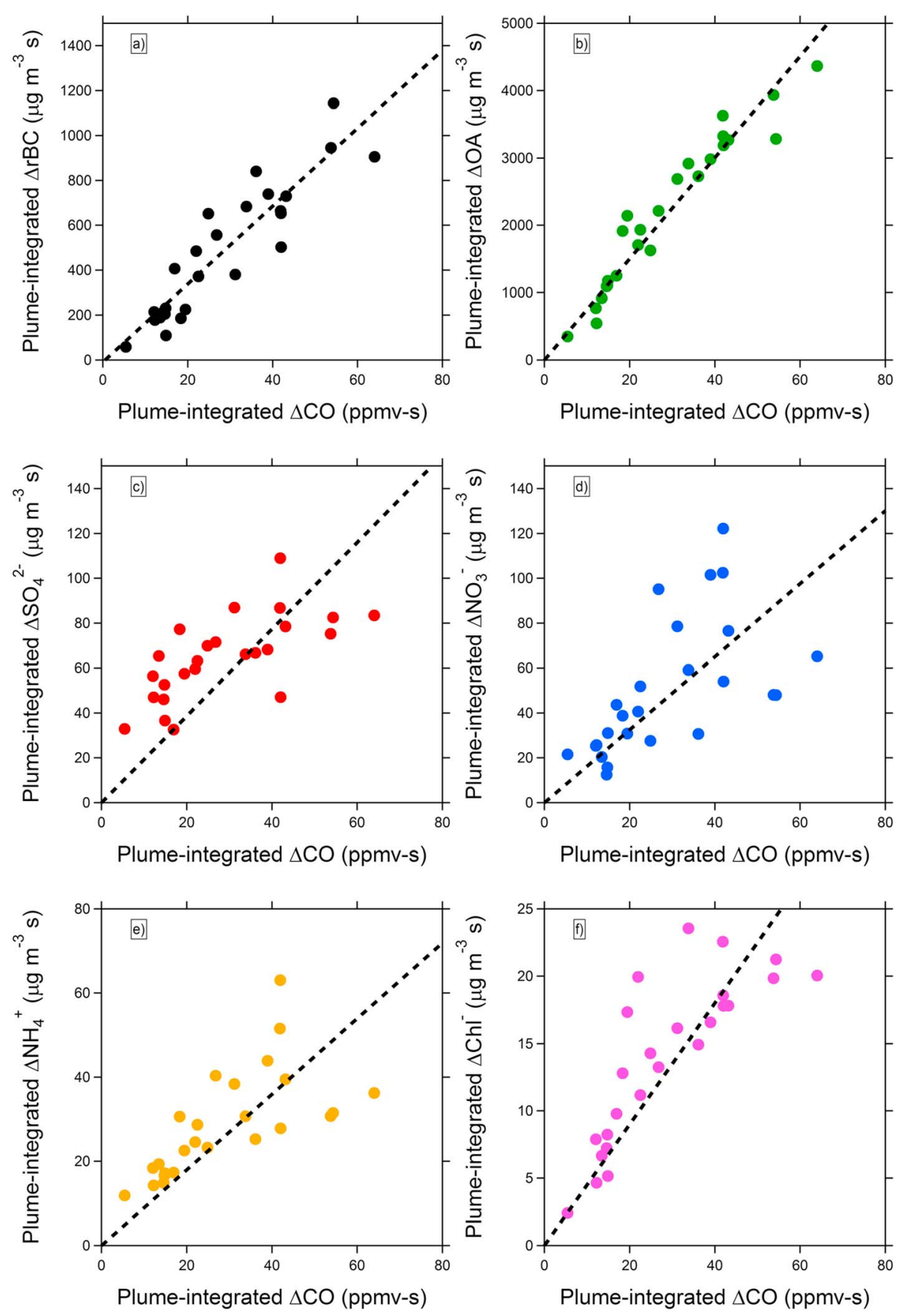

Figure 4. Relationships between excess plume-integrated constituents of $\mathrm{PM}_{1}$ based on SP2 and AMS measurements and excess CO from the CRDS for (a) $\Delta \mathrm{rBC}$, (b) $\Delta \mathrm{OA}$, (c) $\Delta \mathrm{NO}_{3}{ }^{-}$, (d) $\Delta \mathrm{SO}_{4}{ }^{2-}$, (e) $\Delta \mathrm{NH}_{4}{ }^{+}$, and (f) $\Delta \mathrm{Chl}^{-}$for the Fort Jackson $22 \mathrm{~b}$ fire on 2 November 2011. Lines show the regression of each species against $\Delta \mathrm{CO}$. Each point represents a single plume intercept within $5 \mathrm{~km}$ of the source. Uncertainties in these measurements (not shown) are the same as described in Figure 3.

highest OA mass concentrations (e.g., montane species). The fire-averaged mass concentrations in the laboratory chamber for the montane fuels were $4620 \pm 1430 \mu \mathrm{g} \mathrm{sm}^{-3}$ compared to average plumeintegrated OA mass concentrations of $185 \pm 15 \mu \mathrm{g} \mathrm{sm}{ }^{-3}$ observed on the aircraft over montane prescribed fires. A similar argument likely explains the roughly factor of 4 difference in ER $\mathrm{OA}_{\mathrm{A}}$ between SE coastal fuels studied during FLAME-III and the aircraft sampling during SCREAM. Furthermore, ER $\mathrm{OA}_{\mathrm{O}}$ will also be sensitive to $\mathrm{ER}_{\mathrm{tot}}$, the emission ratio of all semivolatile organics (representing both the gas and particle phase) that may undergo gas-particle partitioning [Robinson et al., 2010; May et al., 2013]. ER tot $_{\text {can }}$ be estimated using derived 
volatility distributions, such as that presented as a laboratory composite by May et al. [2013]. However, to our knowledge, this is one of three volatility distributions derived for biomass burning OA emissions thus far (with the others being Cappa and Jimenez [2010], which was derived from AMS positive matrix factorization results, and Grieshop et al. [2009a], which was derived from emissions from a wood stove); none of these volatility distributions have been widely confirmed as representative of biomass burning emissions in the field, so we do not provide estimates of $\mathrm{ER}_{\text {tot }}$ in this work. We simply note that $\mathrm{ER}_{\mathrm{OA}}$ is expected to be greater when $\mathrm{OA}$ concentrations are larger and to decrease with dilution.

\subsubsection{Emission Factors}

As with the $\mathrm{rBC}$ emissions, we converted the emission ratios of measured $\mathrm{OA}$ to emission factors using $\mathrm{EF}_{\mathrm{CO}}$ and provide them in Table 4 and Figure $3 \mathrm{~b}$ (note the split axis). As with emission ratios, $O A$ emission factors ( $\mathrm{EF}_{\mathrm{OA}}$ ) were generally the highest of all the measured aerosol species. Average aircraft-measured $\mathrm{EF}_{\mathrm{OA}}$ were $3.9 \pm 1.8 \mathrm{~g}$ $\mathrm{OA} \mathrm{kg} \mathrm{fuel}^{-1}$ for chaparral fires (excluding the Atmore fire, as discussed in section 3.1), $11.2 \pm 2.7 \mathrm{~g} \mathrm{OA} \mathrm{kg} \mathrm{fuel}^{-1}$ for montane fires, and $2.8 \pm 1.6 \mathrm{~g} \mathrm{OA} \mathrm{kg} \mathrm{fuel}^{-1}$ for SE coastal plain fires. Results for the SE coastal plain differ than those previously reported by Akagi et al. [2013] due to an updated analysis of the AMS data.

These results indicate that fresh organic aerosol emissions from fires can be highly variable, even within the same ecosystem, consistent with previous work [McMeeking et al., 2009; Akagi et al., 2011; Hosseini et al., 2013]. This variability is also observed in the laboratory data for a given ecosystem; for example, the average $\mathrm{EF}_{\mathrm{OA}}$ for $\mathrm{SE}$ coastal plain fuels were $11.5 \pm 13.8 \mathrm{~g} \mathrm{OA} \mathrm{kg} \mathrm{fuel}^{-1}$ during the laboratory portion of this study. $\mathrm{EF}_{\mathrm{OA}}$ were anticorrelated with $\mathrm{MCE}$, as expected for smoldering combustion and as demonstrated for laboratory burns in McMeeking et al. [2009], although the strength of this relationship can be degraded by gas-particle partitioning effects. We also compare the $\mathrm{EF}_{\mathrm{OA}}$ data to the linear fit for $\mathrm{EF}_{\mathrm{OC}}$ from McMeeking et al. [2009] in Figure 3b, after converting OC to OA using OA:OC ratios of 1.2 (reduced hydrocarbons as reported in Turpin and Lim [2001]), 1.6 (the approximate average value from two biomass fuels reported in Aiken et al. [2008]), and 2.0 (the approximate value reported for fireplace wood in Turpin and Lim [2001]). This converted linear fit agrees with some of the FLAME-III data (namely, those with higher-fuel moisture contents that were not montane fuels) but not other FLAME-III data or the airborne data. This variable agreement may be, in part, due to the only modest $R^{2}$ between $\mathrm{MCE}$ and $\mathrm{EF}_{\mathrm{OC}}$ reported in McMeeking et al. [2009] (0.36); for our data, we calculate an $R^{2}$ value of 0.47 . However, fuel moisture content and OA loading also play a role on the magnitude of $\mathrm{EF}_{\mathrm{OA}}$, which will increase the apparent variability in the $M C E$ versus $\mathrm{EF}_{\mathrm{OA}}$ relationship. These dependencies of EF on fuel moisture content and OA mass concentrations suggest that future laboratory studies should report both fire-averaged OA concentrations and fuel moisture contents in addition to ER and/or EF in order to accurately extrapolate laboratory data into chemical transport models used to simulate air quality impacts of wildfires.

Figures $3 \mathrm{c}-3 \mathrm{f}$ and Table 4 also provide EF for submicron nonrefractory inorganic aerosol species measured by the AMS $\left(\mathrm{SO}_{4}{ }^{2-}, \mathrm{NO}_{3}{ }^{-}, \mathrm{NH}_{4}{ }^{+}\right.$, and $\left.\mathrm{Chl}^{-}\right)$as a function of MCE. In general, inorganic EFs were weakly dependent on $\mathrm{MCE}$, in contrast to $\mathrm{rBC}$ and $\mathrm{OA}$, and appeared to have a greater dependence on the type of fuel burned; values of $R^{2}$ were $0.049,0.547,0.047$, and 0.025 for $\mathrm{SO}_{4}{ }^{2-}, \mathrm{NO}_{3}{ }^{-}, \mathrm{NH}_{4}{ }^{+}$, and $\mathrm{Chl}^{-}$, respectively, suggesting that among these species, only $\mathrm{NO}_{3}{ }^{-}$exhibits a dependency on MCE. For example, grasses burned in the laboratory and during prescribed burns (Georgetown fire) tended to have higher $\mathrm{Chl}^{-} \mathrm{EF}_{\text {, }}$ consistent with typically higher fuel chlorine content compared to other fuels [Lobert et al., 1999]. Similarly, both Christian et al. [2003] and Hosseini et al. [2013] found a strong relationship between fuel chlorine content and chloride-containing particulate emissions for a series of laboratory fires. We lack detailed fuel composition information to perform a similar analysis for the aircraft studies, but such a fuel-composition dependence is consistent with our results.

Our aircraft measurements provide some estimates of inorganic emissions for prescribed fires for several ecosystems, as summarized in Table 4. While we lack a mechanistic driver of the factors controlling the emissions variability (e.g., fuel chemistry), presumably the elevated $\mathrm{NO}_{3}{ }^{-}$EF for some of the FLAME-III montane fuels are related to elevated fuel nitrogen content, similar to $\mathrm{Chl}^{-}$. Note that we only include species reliably quantified by the standard AMS operation and analysis, so we may be excluding some refractory salts (e.g., potassium chloride $\mathrm{KCl}$ ) that do not vaporize readily in the instrument. However, the $\mathrm{Chl}^{-}$emission factors reported in Table 4 are in reasonable agreement with filter-based data from previous studies that investigated fuels from chaparral, montane, and SE coastal plain ecosystems 


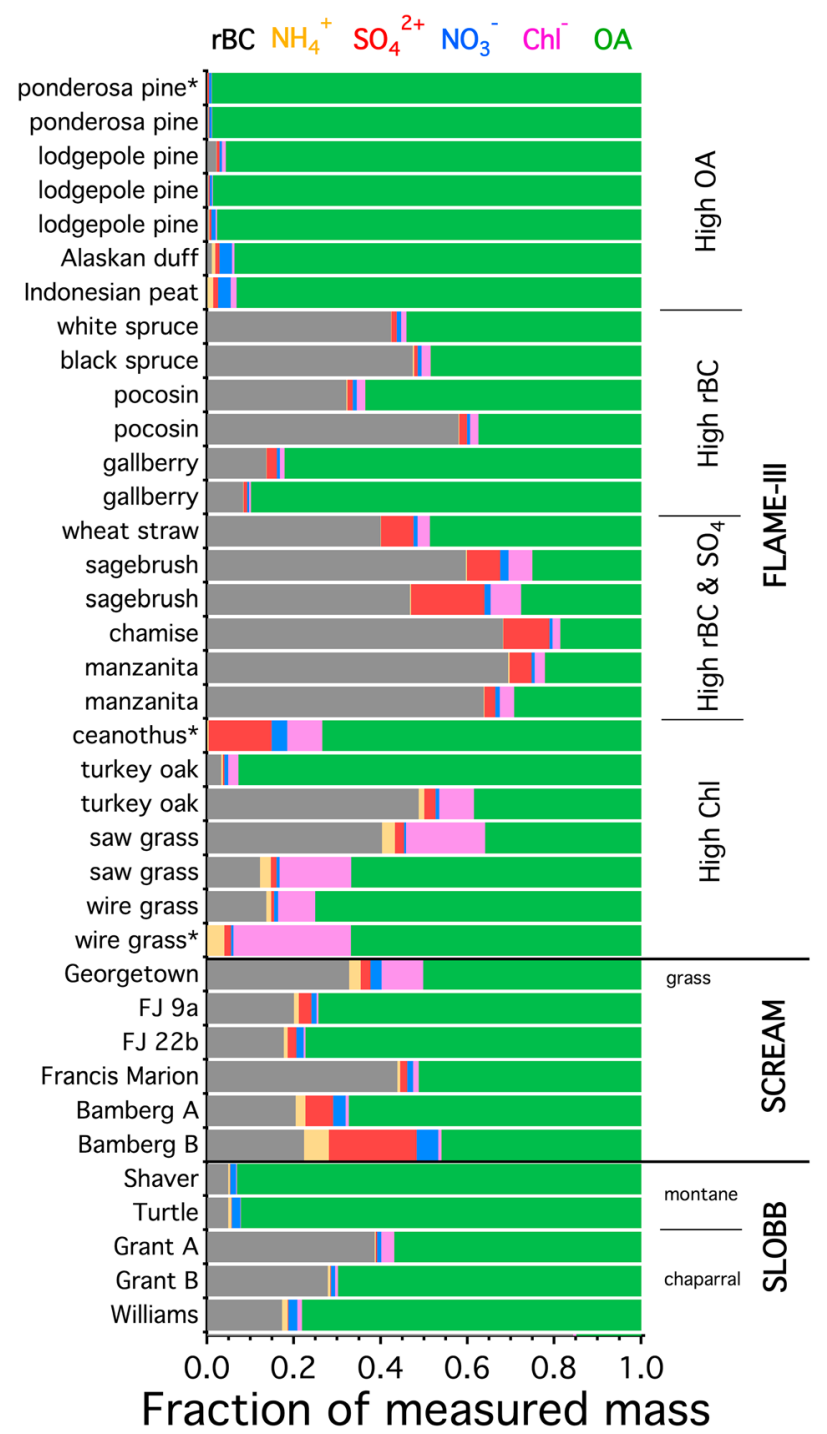

Figure 5. Mass fractions of major species measured in submicron aerosol for laboratory and aircraft measurements. Fuels with asterisk $\left(^{*}\right)$ do not include rBC in mass fraction calculations due to lack of data. The campaign during which the data were collected is provided to the right of the bars. Note that the mass fractions of $\mathrm{OA}$ for the pine species studied in the laboratory may be biased high due to high-fuel moisture contents.
[McMeeking et al., 2009; Hosseini et al., 2013], so it is unlikely that any $\mathrm{Chl}^{-}$is missing from our samples, even if we are not detecting the $\mathrm{K}^{+}$that it may have been paired within the particles.

\subsection{Total Aerosol Emissions}

We combined our measurements of $\mathrm{rBC}$ and nonrefractory submicron aerosol components to investigate the variability in aerosol composition emitted from prescribed fires. Figure 5 shows mass fractions for each species relative to total measured submicron PM $\left(\mathrm{PM}_{1}\right)$, calculated from the sum of SP2 rBC and AMS-measured nonrefractory species. The FLAME-III results presented in this figure from combined SP2 and AMS measurements are qualitatively similar to filter-based results for repeated fuels investigated during previous FLAME studies [Levin et al., 2010]. The laboratory fires produced a wide range of aerosol compositions, which we loosely classified into high $\mathrm{OA}$, high $\mathrm{rBC}$, high $\mathrm{rBC}+\mathrm{SO}_{4}{ }^{2-}$, and high $\mathrm{Chl}^{-}$groups. High OA emitters were mostly pines and dense fuels such as duff and peat, which all had higher-fuel moisture contents. Most other fuels emitted higher-mass fractions of $\mathrm{rBC}$ (10-60\%). Chaparral fuels tended to emit higher-mass fractions of $\mathrm{SO}_{4}{ }^{2-}$, while grass fuels emitted relatively high mass fractions of $\mathrm{Chl}^{-}$. Prescribed fire emissions rarely had inorganic mass fractions as high as observed in the laboratory; the only exceptions were the prescribed grass fire (Georgetown fire) that emitted relatively high mass fractions of $\mathrm{ChI}^{-}$and $\mathrm{NH}_{4}{ }^{+}$ and the Bamberg fires which had large

amounts of $\mathrm{NO}_{3}{ }^{-}$and $\mathrm{SO}_{4}{ }^{2-}$. The exact cause of these discrepancies between the laboratory and field is largely unknown.

Some mass fractions of rBC between laboratory burns and prescribed fires did not agree very well. For example, the montane pine species studied during FLAME-III have nearly negligible rBC fractions, while the PM from the Shaver and Turtle fires were roughly 5\% rBC; the main driver of this discrepancy was likely the very high OA emissions that dominated total PM during these laboratory fires. Some of this difference may be due to differences in OA concentrations and the fuel burned in the field versus the laboratory. Conversely, chaparral prescribed fires generally had the highest-rBC emissions, while laboratory fuels such as ceanothus, chamise, and manzanita, which were combusted during the chaparral fires [Burling et al., 2011], generally had the highest-rBC mass fractions in the emissions measured during FLAME-III.

In Tables 3 and 4, we also provide ER and EF for $\mathrm{PM}_{1}$. For our aircraft data, SE U.S. coastal plain fires had the lowest average $\mathrm{PM}_{1} \mathrm{EF}\left(4.4 \pm 2.0 \mathrm{~g} \mathrm{~kg} \mathrm{fuel}^{-1}\right)$ emission factors, followed by chaparral (excluding Atmore) 
$\left(\mathrm{PM}_{1} \mathrm{EF}=5.5 \pm 1.7 \mathrm{~g} \mathrm{~kg} \mathrm{fuel}^{-1}\right)$ and montane $\left(\mathrm{PM}_{1} \mathrm{EF}=12.1 \pm 2.9 \mathrm{~g} \mathrm{~kg} \mathrm{fuel}^{-1}\right)$ fires. Based on $\mathrm{PM}_{2.5}$ measurements in prior work [McMeeking et al., 2009; Hosseini et al., 2013], these estimates of $\mathrm{PM}_{1}$ may be biased low by roughly 1-10\% due to missing potassium; furthermore, Levin et al. [2010] report that emissions of refractory salts (e.g., $\mathrm{KCl}, \mathrm{K}_{2} \mathrm{SO}_{4}$, and $\mathrm{NaCl}$ ) and minerals (e.g., calcium oxide) may represent up to $50 \%$ of the emitted particle mass, depending on fuel type. The differences between ecosystems were mainly due to differences in $\mathrm{OA}$ emissions, which represented the majority of the emitted $\mathrm{PM}_{1}$. Our aircraft observations of $\mathrm{PM}_{1}$ were approximately within the range of values of $12.7 \pm 7.5 \mathrm{~g} \mathrm{~kg} \mathrm{fuel}^{-1}$ recommended by Akagi et al. [2011] for $\mathrm{PM}_{2.5}$ emitted by temperate forests. Our data also highlight the substantial natural variability in fire emissions due to differences in ecosystems, fuel moisture content, fire intensity, and vegetation cover; for example, the relative standard deviation (standard deviation divided by the average) for the ecosystems that we considered ranged from 0.24 for montane fires to 0.45 for SE U.S. coastal plain fires.

\section{Conclusions}

In this paper we report measured EFs and ERs for key submicron aerosol components in emissions from prescribed burns in three U.S. ecosystems (chaparral, montane, and SE coastal plain) and compare with EFs and ERs for similar fuels measured in some open laboratory burns. Refractory black carbon aerosol was measured using a laser-induced incandescence technique (SP2) rather than the more traditional filter-based absorption/thermal-optical methods, with measured $\mathrm{EF}_{\mathrm{rBC}}$ ranging from approximately 0 to $3 \mathrm{~g} \mathrm{~kg} \mathrm{fuel}^{-1}$ depending on fuel and combustion conditions. $\mathrm{EF}_{\mathrm{rBC}}$ measured in the laboratory were consistent with those measured in the field from the aircraft, suggesting laboratory-derived values can adequately represent largerscale fires when MCE is used to characterize the burn conditions. Organic aerosol emissions measured in the laboratory had a much wider range of observed values $\left(\mathrm{EF}_{\mathrm{OA}}=<1-200 \mathrm{~g} \mathrm{~kg} \mathrm{fuel}^{-1}\right)$ compared to aircraft measurements $\left(\mathrm{EF}_{\mathrm{OA}}=0.2-13 \mathrm{~g} \mathrm{~kg} \mathrm{fuel}^{-1}\right)$ and appeared to depend strongly on fuel moisture content and the OA mass concentration, as suggested by May et al. [2013], as well as MCE, although there were some exceptions. The evolution of $\mathrm{OA}$ with dilution and atmospheric processing will affect its concentrations downwind of source regions and remains a topic of active research (e.g., see Hennigan et al. [2011]; May et al. [2013]; Ortega et al. [2013], and E. J. T. Levin et al. (in preparation, 2014) for analysis of FLAME-III data; A. A. May et al. (in preparation, 2014) for analysis of SCREAM data; and Akagi et al. [2012] for analysis of SLOBB data). Inorganic emission factors were always smaller than $\mathrm{rBC}$ and $\mathrm{OA}$ emission factors and depended somewhat on fuel type, though fuels burned in the laboratory tended to emit relatively higher mass fractions of inorganics compared to prescribed fires measured in the field. One notable exception was relatively high chloride mass fraction in emissions measured over a prescribed coastal grass fire in South Carolina.

It is of interest to compare the range of observed $\mathrm{ER}_{\mathrm{rBC}}$ for our biomass burning samples with those reported for other BC sources, which are primarily contained combustion such as vehicular and industrial emissions [Bond et al., 2013]. Spackman et al. [2008] compared the biomass burning plume measurements described in Schwarz et al. [2008] to regional urban and industrial plumes observed over Texas and found lower $E_{\mathrm{rBC}}$ ( $7.5 \mathrm{ng} \mathrm{BC} \mathrm{sm}^{-3} \mathrm{ppbv} \mathrm{CO}^{-1}$ ) for the urban emissions compared to biomass burning emissions. Others have also reported similar and/or lower $\mathrm{ER}_{\mathrm{rBC}}$ for urban regions [Baumgardner et al., 2007; McMeeking et al., 2010; Subramanian et al., 2010; Sahu et al., 2012]. Although the ecosystem-averaged ER $_{\mathrm{rBC}}$ values we observed for chaparral and SE coastal plain fires and the Schwarz et al. [2008] observations were 2-3 times higher than the largest observed urban $\mathrm{ER}_{\mathrm{rBC}}$ ratios, our montane fire values and the $\mathrm{ER}_{\mathrm{rBC}}$ values reported by Kondo et al. [2011b] fall within the range of reported urban $\mathrm{ER}_{\mathrm{r} B C}$. Thus, $\mathrm{ER}_{\mathrm{rBC}}$ alone is not a sufficient parameter for distinguishing between biomass burning and urban $\mathrm{BC}$ sources in modeling studies, and their relative contributions to an ambient sample cannot be determined without additional information (e.g., MCE) on the characteristics of the prescribed or wildfire considered.

The SP2-derived EF and ER for refractory black carbon in this work are consistently higher than previously reported values based on filter sampling with absorption/thermal-optical analyses, which may suggest that EF and ER for $\mathrm{rBC}$ in existing emissions inventories may require an increase via the inclusion of these newer, SP2-derived data in the average inventory values. However, systematic intercomparisons between the SP2 and filter-based techniques are required to confirm the robustness of this finding to determine whether this is a systematic difference or natural variability. Additional studies, especially in important biomass burning regions in the tropics, are needed to determine whether this revision is needed for all ecosystems or only for those studied in this work. 


\section{Acknowledgments}

We thank the USFS Twin Otter pilots Bill Mank and Scott Miller and mechanic Steve Woods for their contribution to the SLOBB and SCREAM campaigns and the USFS JeffCo aircraft base, San Luis Aviation, Eagle Aviation, the NSF/NCAR Research Aviation Facility, and Ezra Levin for their contributions to the installation of instruments on the Twin Otter and its deployment to the field. Adaptation of the Twin Otter for atmospheric measurements and other support was provided by NSF grants ATM-0531055 and ATM-0936321 to R.Y. Prescribed fires were organized and carried out by John Maitland and forestry staff at Fort Jackson and Dan Ardoin at Vandenberg AFB. We also thank Jason McCarty of the Santa Barbara County Fire Department for conducting burns and providing fuels and weather information during SLOBB. Fuel inventories and other ground-based information were provided by Jim Reardon, Aaron Sparks, and Signe Leirfallom. We thank the USFS Fire Science Laboratory staff and the FLAMEIII participants for their contributions to the laboratory measurements. We also thank Shane Murphy, Roya Bahreini, and Ann Middlebrook for their suggestions and assistance in modifying the Colorado State University AMS for aircraft operation during SCREAM; furthermore, Tim Onasch, Jose Jimenez, and Misha Schurman all contributed to discussions regarding AMS analysis of the SCREAM data. G.R. McMeeking's participation in FLAME-III was supported by the UK Royal Society. The California aircraft measurements were supported by the Strategic Environmental Research and Development Program (SERDP) projects SI-1648 and SI-1649 and the SP2 was supported by the UK Natural Environment Research Council (NERC) We acknowledge funding from the Joint Fire Science Program under project JFSP 11-1-5-12 for the South Carolina aircraft measurements and related AMS data analysis. The Fort Jackson study was supported by SERDP project RC-1649 administered partly through the Forest Service Research Joint Venture Agreement 08JV11272166039. Additional flight hours and SCREAM CRDS data were provided by Joint Fire Science Program project 08-1-6-09. To request copies of the data used in this paper, please contact the corresponding author. Finally, we would like to thank our editor, Lynn Russell, and the anonymous reviewers for their useful comments.

\section{References}

Aiken, A. C., et al. (2008), O/C and OM/OC ratios of primary, secondary, and ambient organic aerosols with high-resolution time-of-flight aerosol mass spectrometry, Environ. Sci. Technol., 42(12), 4478-4485, doi:10.1021/es703009q.

Akagi, S. K., R. J. Yokelson, C. Wiedinmyer, M. J. Alvarado, J. S. Reid, T. Karl, J. D. Crounse, and P. O. Wennberg (2011), Emission factors for open and domestic biomass burning for use in atmospheric models, Atmos. Chem. Phys., 11(9), 4039-4072, doi:10.5194/acp-11-4039-2011.

Akagi, S. K., et al. (2012), Evolution of trace gases and particles emitted by a chaparral fire in California, Atmos. Chem. Phys., 12(3), 1397-1421, doi:10.5194/acp-12-1397-2012.

Akagi, S. K., et al. (2013), Measurements of reactive trace gases and variable $\mathrm{O}_{3}$ formation rates in some South Carolina biomass burning plumes, Atmos. Chem. Phys., 13(3), 1141-1165, doi:10.5194/acp-13-1141-2013.

Akagi, S. K., I. R. Burling, A. Mendoza, T. J. Johnson, M. Cameron, D. W. T. Griffith, C. Paton-Walsh, D. R. Weise, J. Reardon, and R. J. Yokelson (2014), Field measurements of trace gases emitted by prescribed fires in southeastern US pine forests using an open-path FTIR system, Atmos. Chem. Phys., 14(1), 199-215, doi:10.5194/acp-14-199-2014.

Allan, J. D., et al. (2004), A generalised method for the extraction of chemically resolved mass spectra from Aerodyne aerosol mass spectrometer data, J. Aerosol Sci., 35(7), 909-922, doi:10.1016/j.jaerosci.2004.02.007.

Allen, S. E., H. M. Grimshaw, J. A. Parkinson, and C. Quarmby (1974), Chemical Analysis of Ecological Materials, Blackwell Sci., Oxford, U. K. Andreae, M. O., and A. Gelencsér (2006), Black carbon or brown carbon? The nature of light-absorbing carbonaceous aerosols, Atmos. Chem. Phys., 6(10), 3131-3148, doi:10.5194/acp-6-3131-2006.

Andreae, M. O., and P. Merlet (2001), Emission of trace gases and aerosols from biomass burning, Global Biogeochem. Cycles, 15(4), 955-966, doi:10.1029/2000GB001382.

Aurell, J., and B. K. Gullett (2013), Emission factors from aerial and ground measurements of field and laboratory forest burns in the southeastern US: PM2.5, black and brown carbon, VOC, and PCDD/PCDF, Environ. Sci. Technol., 47(15), 8443-8452, doi:10.1021/es402101k.

Bae, M.-S., J. J. Schwab, Q. Zhang, O. Hogrefe, K. L. Demerjian, S. Weimer, K. Rhoads, D. Orsini, P. Venkatachari, and P. K. Hopke (2007), Interference of organic signals in highly time resolved nitrate measurements by low mass resolution aerosol mass spectrometry, J. Geophys. Res., 112, D22305, doi:10.1029/2007JD008614.

Bahreini, R., et al. (2009), Organic aerosol formation in urban and industrial plumes near Houston and Dallas, Texas, J. Geophys. Res., 114, D00F16, doi:10.1029/2008JD011493.

Baumgardner, D., G. L. Kok, and G. B. Raga (2004), Warming of the Arctic lower stratosphere by light absorbing particles, Geophys. Res. Lett., 31, L06117, doi:10.1029/2003GL018883.

Baumgardner, D., G. L. Kok, and G. B. Raga (2007), On the diurnal variability of particle properties related to light absorbing carbon in Mexico City, Atmos. Chem. Phys., 7(10), 2517-2526, doi:10.5194/acp-7-2517-2007.

Baumgardner, D., et al. (2012), Soot reference materials for instrument calibration and intercomparisons: A workshop summary with recommendations, Atmos. Meas. Tech., 5(8), 1869-1887, doi:10.5194/amt-5-1869-2012.

Bond, T. C., and R. W. Bergstrom (2006), Light absorption by carbonaceous particles: An investigative review, Aerosol Sci. Technol., 40(1), 27-67, doi:10.1080/02786820500421521.

Bond, T. C., D. G. Streets, K. F. Yarber, S. M. Nelson, J. H. Woo, and Z. Klimont (2004), A technology-based global inventory of black and organic carbon emissions from combustion, J. Geophys. Res., 109, D14203, doi:10.1029/2003JD003697.

Bond, T. C., et al. (2013), Bounding the role of black carbon in the climate system: A scientific assessment, J. Geophys. Res. Atmos., 118, 5380-5552, doi:10.1002/jgrd.50171.

Burling, I. R., R. J. Yokelson, S. K. Akagi, S. P. Urbanski, C. E. Wold, D. W. T. Griffith, T. J. Johnson, J. Reardon, and D. R. Weise (2011), Airborne and ground-based measurements of the trace gases and particles emitted by prescribed fires in the United States, Atmos. Chem. Phys., 11(23), 12,197-12,216, doi:10.5194/acp-11-12197-2011.

Canagaratna, M. R., et al. (2007), Chemical and microphysical characterization of ambient aerosols with the aerodyne aerosol mass spectrometer, Mass Spectrom. Rev., 26(2), 185-222, doi:10.1002/mas.20115.

Capes, G., B. Johnson, G. McFiggans, P. I. Williams, J. Haywood, and H. Coe (2008), Aging of biomass burning aerosols over West Africa: Aircraft measurements of chemical composition, microphysical properties, and emission ratios, J. Geophys. Res., 113, D00C15, doi:10.1029/ 2008JD009845.

Cappa, C. D., and J. L. Jimenez (2010), Quantitative estimates of the volatility of ambient organic aerosol, Atmos. Chem. Phys., 10(12), 5409-5424, doi:10.5194/acp-10-5409-2010.

Cappa, C. D., D. A. Lack, J. B. Burkholder, and A. R. Ravishankara (2008), Bias in filter-based aerosol light absorption measurements due to organic aerosol loading: Evidence from laboratory measurements, Aerosol Sci. Technol., 42(12), 1022-1032, doi:10.1080/02786820802389285.

Carter, M. C., and C. D. Foster (2004), Prescribed burning and productivity in southern pine forests: A review, For. Ecol. Manage., 191(1-3), 93-109, doi:10.1016/j.foreco.2003.11.006.

Chen, L.-W. A., P. Verburg, A. Shackelford, D. Zhu, R. Susfalk, J. C. Chow, and J. G. Watson (2010), Moisture effects on carbon and nitrogen emission from burning of wildland biomass, Atmos. Chem. Phys., 10(14), 6617-6625, doi:10.5194/acp-10-6617-2010.

Chow, J. C., J. G. Watson, L.-W. A. Chen, W. P. Arnott, H. Moosmüller, and K. Fung (2004), Equivalence of elemental carbon by thermal/optical reflectance and transmittance with different temperature protocols, Environ. Sci. Technol., 38(16), 4414-4422, doi:10.1021/es034936u.

Chow, J. C., J. G. Watson, L.-W. A. Chen, M. C. O. Chang, N. F. Robinson, D. Trimble, and S. Kohl (2007), The IMPROVE_A temperature protocol for thermal/optical carbon analysis: Maintaining consistency with a long-term database, J. Air Waste Manage. Assoc., 57(9), 1014-1023, doi:10.3155/1047-3289.57.9.1014.

Christian, T. J., B. Kleiss, R. J. Yokelson, R. Holzinger, P. J. Crutzen, W. M. Hao, B. H. Saharjo, and D. E. Ward (2003), Comprehensive laboratory measurements of biomass-burning emissions: 1. Emissions from Indonesian, African, and other fuels, J. Geophys. Res., 108(D23), 4719, doi:10.1029/2003JD003704.

Cubison, M. J., et al. (2011), Effects of aging on organic aerosol from open biomass burning smoke in aircraft and laboratory studies, Atmos. Chem. Phys., 11(23), 12,049-12,064, doi:10.5194/acp-11-12049-2011.

Dahlkötter, F., M. Gysel, D. Sauer, A. Minikin, R. Baumann, P. Seifert, A. Ansmann, M. Fromm, C. Voigt, and B. Weinzierl (2014), The Pagami Creek smoke plume after long-range transport to the upper troposphere over Europe-Aerosol properties and black carbon mixing state, Atmos. Chem. Phys., 14(12), 6111-6137, doi:10.5194/acp-14-6111-2014.

DeCarlo, P. F., et al. (2006), Field-deployable, high-resolution, time-of-flight aerosol mass spectrometer, Anal. Chem., 78(24), 8281-8289, doi:10.1021/ac061249n

DeCarlo, P. F., et al. (2008), Fast airborne aerosol size and chemistry measurements above Mexico City and Central Mexico during the MILAGRO campaign, Atmos. Chem. Phys., 8(14), 4027-4048, doi:10.5194/acp-8-4027-2008. 
DeCarlo, P. F., et al. (2010), Investigation of the sources and processing of organic aerosol over the Central Mexican Plateau from aircraft measurements during MILAGRO, Atmos. Chem. Phys., 10(12), 5257-5280, doi:10.5194/acp-10-5257-2010.

De Gouw, J. A., et al. (2008), Sources of particulate matter in the northeastern United States in summer: 1. Direct emissions and secondary formation of organic matter in urban plumes, J. Geophys. Res., 113, D08301, doi:10.1029/2007JD009243.

Donahue, N. M., A. L. Robinson, C. O. Stanier, and S. N. Pandis (2006), Coupled partitioning, dilution, and chemical aging of semivolatile organics, Environ. Sci. Technol., 40(8), 2635-2643, doi:10.1021/es052297c.

Drewnick, F., et al. (2005), A new time-of-flight aerosol mass spectrometer (TOF-AMS)—Instrument description and first field deployment, Aerosol Sci. Technol., 39(7), 637-658, doi:10.1080/02786820500182040.

Engelhart, G. J., C. J. Hennigan, M. A. Miracolo, A. L. Robinson, and S. N. Pandis (2012), Cloud condensation nuclei activity of fresh primary and aged biomass burning aerosol, Atmos. Chem. Phys., 12(15), 7285-7293, doi:10.5194/acp-12-7285-2012.

Fernandes, P. M., and H. S. Botelho (2003), A review of prescribed burning effectiveness in fire hazard reduction, Int. J. Wildl. Fire, 12(2), 117, doi:10.1071/WF02042.

Flannigan, M. D., M. A. Krawchuk, W. J. de Groot, B. M. Wotton, and L. M. Gowman (2009), Implications of changing climate for global wildland fire, Int. J. Wildl. Fire, 18(5), 483, doi:10.1071/WF08187.

Formenti, P., W. Elbert, W. Maenhaut, J. Haywood, S. Osborne, and M. O. Andreae (2003), Inorganic and carbonaceous aerosols during the Southern African Regional Science Initiative (SAFARI 2000) experiment: Chemical characteristics, physical properties, and emission data for smoke from African biomass burning, J. Geophys. Res., 108(D13), 8488, doi:10.1029/2002JD002408.

Giglio, L., J. T. Randerson, and G. R. van der Werf (2013), Analysis of daily, monthly, and annual burned area using the fourth-generation global fire emissions database (GFED4), J. Geophys. Res. Biogeosci., 118, 317-328, doi:10.1002/jgrg.20042.

Grieshop, A. P., M. A. Miracolo, N. M. Donahue, and A. L. Robinson (2009a), Constraining the volatility distribution and gas-particle partitioning of combustion aerosols using isothermal dilution and thermodenuder measurements, Environ. Sci. Technol., 43(13), 4750-4756, doi:10.1021/es8032378.

Grieshop, A. P., J. M. Logue, N. M. Donahue, and A. L. Robinson (2009b), Laboratory investigation of photochemical oxidation of organic aerosol from wood fires 1: Measurement and simulation of organic aerosol evolution, Atmos. Chem. Phys., 9(4), 1263-1277, doi:10.5194/ acp-9-1263-2009.

Gysel, M., M. Laborde, J. S. Olfert, R. Subramanian, and A. J. Gröhn (2011), Effective density of Aquadag and fullerene soot black carbon reference materials used for SP2 calibration, Atmos. Meas. Tech., 4(12), 2851-2858, doi:10.5194/amt-4-2851-2011.

Hayashi, K., K. Ono, M. Kajiura, S. Sudo, S. Yonemura, A. Fushimi, K. Saitoh, Y. Fujitani, and K. Tanabe (2014), Trace gas and particle emissions from open burning of three cereal crop residues: Increase in residue moistness enhances emissions of carbon monoxide, methane, and particulate organic carbon, Atmos. Environ., doi:10.1016/j.atmosenv.2014.06.023.

Hecobian, A., et al. (2011), Comparison of chemical characteristics of 495 biomass burning plumes intercepted by the NASA DC-8 aircraft during the ARCTAS/CARB-2008 field campaign, Atmos. Chem. Phys., 11(24), 13,325-13,337, doi:10.5194/acp-11-13325-2011.

Heilman, W. E., Y. Liu, S. Urbanski, V. Kovalev, and R. Mickler (2014), Wildland fire emissions, carbon, and climate: Plume rise, atmospheric transport, and chemistry processes, For. Ecol. Manage., 317, 70-79, doi:10.1016/j.foreco.2013.02.001.

Hennigan, C. J., et al. (2011), Chemical and physical transformations of organic aerosol from the photo-oxidation of open biomass burning emissions in an environmental chamber, Atmos. Chem. Phys., 11(15), 7669-7686, doi:10.5194/acp-11-7669-2011.

Hennigan, C. J., D. M. Westervelt, I. Riipinen, G. J. Engelhart, T. Lee, J. L. Collett, S. N. Pandis, P. J. Adams, and A. L. Robinson (2012), New particle formation and growth in biomass burning plumes: An important source of cloud condensation nuclei, Geophys. Res. Lett., 39, L09805, doi:10.1029/2012GL050930.

Heringa, M. F., P. F. DeCarlo, R. Chirico, T. Tritscher, J. Dommen, E. Weingartner, R. Richter, G. Wehrle, A. S. H. Prévôt, and U. Baltensperger (2011), Investigations of primary and secondary particulate matter of different wood combustion appliances with a high-resolution timeof-flight aerosol mass spectrometer, Atmos. Chem. Phys., 11(12), 5945-5957, doi:10.5194/acp-11-5945-2011.

Hosseini, S., et al. (2013), Laboratory characterization of PM emissions from combustion of wildland biomass fuels, J. Geophys. Res. Atmos. 118, 9914-9929, doi:10.1002/jgrd.50481.

Hu, Y., M. T. Odman, M. E. Chang, W. Jackson, S. Lee, E. S. Edgerton, K. Baumann, and A. G. Russell (2008), Simulation of air quality impacts from prescribed fires on an urban area, Environ. Sci. Technol., 42(10), 3676-3682, doi:10.1021/es071703k.

Huffman, J. A., K. S. Docherty, C. Mohr, M. J. Cubison, I. M. Ulbrich, P. J. Ziemann, T. B. Onasch, and J. L. Jimenez (2009), Chemicallyresolved volatility measurements of organic aerosol from different sources, Environ. Sci. Technol., 43(14), 5351-5357, doi:10.1021/ es803539d.

Jimenez, J. L., et al. (2009), Evolution of organic aerosols in the atmosphere, Science, 326(5959), 1525-9, doi:10.1126/science.1180353.

Jolleys, M. D., et al. (2012), Characterizing the aging of biomass burning organic aerosol by use of mixing ratios: A meta-analysis of four regions, Environ. Sci. Technol., 46(24), 13,093-13,102, doi:10.1021/es302386v.

Kirchstetter, T. W., T. Novakov, and P. V. Hobbs (2004), Evidence that the spectral dependence of light absorption by aerosols is affected by organic carbon, J. Geophys. Res., 109, D21208, doi:10.1029/2004JD004999.

Koch, D., et al. (2009), Evaluation of black carbon estimations in global aerosol models, Atmos. Chem. Phys., 9(22), 9001-9026, doi:10.5194/ acp-9-9001-2009.

Kondo, Y., L. Sahu, N. Moteki, F. Khan, N. Takegawa, X. Liu, M. Koike, and T. Miyakawa (2011a), Consistency and traceability of black carbon measurements made by laser-induced incandescence, thermal-optical transmittance, and filter-based photo-absorption techniques, Aerosol Sci. Technol., 45(2), 295-312, doi:10.1080/02786826.2010.533215.

Kondo, Y., et al. (2011b), Emissions of black carbon, organic, and inorganic aerosols from biomass burning in North America and Asia in 2008 , J. Geophys. Res., 116, D08204, doi:10.1029/2010JD015152.

Laborde, M., P. Mertes, P. Zieger, J. Dommen, U. Baltensperger, and M. Gysel (2012), Sensitivity of the Single Particle Soot Photometer to different black carbon types, Atmos. Meas. Tech., 5(5), 1031-1043, doi:10.5194/amt-5-1031-2012.

Lack, D. A., and C. D. Cappa (2010), Impact of brown and clear carbon on light absorption enhancement, single scatter albedo and absorption wavelength dependence of black carbon, Atmos. Chem. Phys., 10(9), 4207-4220, doi:10.5194/acp-10-4207-2010.

Lack, D. A., C. D. Cappa, D. S. Covert, T. Baynard, P. Massoli, B. Sierau, T. S. Bates, P. K. Quinn, E. R. Lovejoy, and A. R. Ravishankara (2008), Bias in filter-based aerosol light absorption measurements due to organic aerosol loading: Evidence from ambient measurements, Aerosol Sci. Technol., 42(12), 1033-1041, doi:10.1080/02786820802389277.

Lack, D. A., J. M. Langridge, R. Bahreini, C. D. Cappa, A. M. Middlebrook, and J. P. Schwarz (2012), Brown carbon and internal mixing in biomass burning particles, Proc. Natl. Acad. Sci. U. S. A., 109(37), 14,802-14,807, doi:10.1073/pnas.1206575109.

Levin, E. J. T., et al. (2010), Biomass burning smoke aerosol properties measured during Fire Laboratory at Missoula Experiments (FLAME), J. Geophys. Res., 115, D18210, doi:10.1029/2009JD013601. 
Lewis, K., W. P. Arnott, H. Moosmüller, and C. E. Wold (2008), Strong spectral variation of biomass smoke light absorption and single scattering albedo observed with a novel dual-wavelength photoacoustic instrument, J. Geophys. Res., 113, D16203, doi:10.1029/2007JD009699.

Liggio, J., M. Gordon, G. Smallwood, S.-M. Li, C. Stroud, R. Staebler, G. Lu, P. Lee, B. Taylor, and J. R. Brook (2012), Are emissions of black carbon from gasoline vehicles underestimated? Insights from near and on-road measurements, Environ. Sci. Technol., 46(9), 4819-4828, doi:10.1021/es2033845.

Lipsky, E. M., and A. L. Robinson (2006), Effects of dilution on fine particle mass and partitioning of semivolatile organics in diesel exhaust and wood smoke, Environ. Sci. Technol., 40(1), 155-162, doi:10.1021/es050319p.

Liu, D., et al. (2011), Carbonaceous aerosols contributed by traffic and solid fuel burning at a polluted rural site in Northwestern England, Atmos. Chem. Phys., 11(4), 1603-1619, doi:10.5194/acp-11-1603-2011.

Liu, Y., S. Goodrick, G. Achtemeier, W. A. Jackson, J. J. Qu, and W. Wang (2009), Smoke incursions into urban areas: Simulation of a Georgia prescribed burn, Int. J. Wildl. Fire, 18(3), 336, doi:10.1071/WF08082.

Lobert, J. M., W. C. Keene, J. A. Logan, and R. Yevich (1999), Global chlorine emissions from biomass burning: Reactive chlorine emissions inventory, J. Geophys. Res., 104(D7), 8373-8389, doi:10.1029/1998JD100077.

Magi, B. I. (2009), Chemical apportionment of southern African aerosol mass and optical depth, Atmos. Chem. Phys., 9(19), 7643-7655, doi:10.5194/acp-9-7643-2009.

May, A. A., E. J. T. Levin, C. J. Hennigan, I. Riipinen, T. Lee, J. L. Collett, J. L. Jimenez, S. M. Kreidenweis, and A. L. Robinson (2013), Gas-particle partitioning of primary organic aerosol emissions: 3. Biomass burning, J. Geophys. Res. Atmos., 118, 11,327-11,338, doi:10.1002/jgrd.50828.

McMeeking, G. R., et al. (2006), Smoke-impacted regional haze in California during the summer of 2002, Agric. For. Meteorol., 137(1-2), 25-42, doi:10.1016/j.agrformet.2006.01.011.

McMeeking, G. R., et al. (2009), Emissions of trace gases and aerosols during the open combustion of biomass in the laboratory, J. Geophys. Res., 114, D19210, doi:10.1029/2009JD011836.

McMeeking, G. R., et al. (2010), Black carbon measurements in the boundary layer over western and northern Europe, Atmos. Chem. Phys., 10(19), 9393-9414, doi:10.5194/acp-10-9393-2010.

McMeeking, G. R., E. Fortner, T. B. Onasch, J. Taylor, M. Flynn, H. Coe, and S. M. Kreidenweis (2014), Impacts of non-refractory material on light absorption by aerosols emitted from biomass burning, J. Geophys. Res. Atmos., doi:10.1002/2014JD021750.

Middlebrook, A. M., R. Bahreini, J. L. Jimenez, and M. R. Canagaratna (2012), Evaluation of composition-dependent collection efficiencies for the aerodyne aerosol mass spectrometer using field data, Aerosol Sci. Technol., 46(3), 258-271, doi:10.1080/02786826.2011.620041.

Miller, J. D., H. D. Safford, M. Crimmins, and A. E. Thode (2008), Quantitative evidence for increasing forest fire severity in the Sierra Nevada and Southern Cascade Mountains, California and Nevada, USA, Ecosystems, 12(1), 16-32, doi:10.1007/s10021-008-9201-9.

Moteki, N., and Y. Kondo (2010), Dependence of laser-induced incandescence on physical properties of black carbon aerosols: Measurements and theoretical interpretation, Aerosol Sci. Technol., 44(8), 663-675, doi:10.1080/02786826.2010.484450.

Moteki, N., Y. Kondo, Y. Miyazaki, N. Takegawa, Y. Komazaki, G. Kurata, T. Shirai, D. R. Blake, T. Miyakawa, and M. Koike (2007), Evolution of mixing state of black carbon particles: Aircraft measurements over the western Pacific in March 2004, Geophys. Res. Lett., 34, L11803, doi:10.1029/2006GL028943.

Murphy, S. M., et al. (2009), Comprehensive simultaneous shipboard and airborne characterization of exhaust from a Modern Container Ship at Sea, Environ. Sci. Technol., 43(13), 4626-4640, doi:10.1021/es802413j.

Ortega, A. M., D. A. Day, M. J. Cubison, W. H. Brune, D. Bon, J. A. de Gouw, and J. L. Jimenez (2013), Secondary organic aerosol formation and primary organic aerosol oxidation from biomass-burning smoke in a flow reactor during FLAME-3, Atmos. Chem. Phys., 13(22), 11,551-11,571, doi:10.5194/acp-13-11551-2013.

Paris, J.-D., A. Stohl, P. Nédélec, M. Y. Arshinov, M. V. Panchenko, V. P. Shmargunov, K. S. Law, B. D. Belan, and P. Ciais (2009), Wildfire smoke in the Siberian Arctic in summer: Source characterization and plume evolution from airborne measurements, Atmos. Chem. Phys., 9(23), 9315-9327, doi:10.5194/acp-9-9315-2009.

Park, R. J., D. J. Jacob, and J. A. Logan (2007), Fire and biofuel contributions to annual mean aerosol mass concentrations in the United States, Atmos. Environ., 41(35), 7389-7400, doi:10.1016/j.atmosenv.2007.05.061.

Petzold, A., et al. (2013), Recommendations for reporting "black carbon" measurements, Atmos. Chem. Phys., 13(16), 8365-8379, doi:10.5194/acp-13-8365-2013.

Phuleria, H. C., P. M. Fine, Y. F. Zhu, and C. Sioutas (2005), Air quality impacts of the October 2003 Southern California wildfires, J. Geophys. Res., 110, D07S20, doi:10.1029/2004JD004626.

Ramanathan, V., and G. Carmichael (2008), Global and regional climate changes due to black carbon, Nat. Geosci., 1(4), 221-227, doi:10.1038/ngeo156.

Reid, J. S., R. Koppmann, T. F. Eck, and D. P. Eleuterio (2005), A review of biomass burning emissions part II: Intensive physical properties of biomass burning particles, Atmos. Chem. Phys., 5(3), 799-825, doi:10.5194/acp-5-799-2005.

Robinson, A. L., N. M. Donahue, M. K. Shrivastava, E. A. Weitkamp, A. M. Sage, A. P. Grieshop, T. E. Lane, J. R. Pierce, S. N. Pandis, and S. Emissions (2007), Rethinking organic aerosols: Semivolatile emissions and photochemical aging, Science, 315(5816), 1259-1262, doi:10.1126/science.1133061.

Robinson, A. L., A. P. Grieshop, N. M. Donahue, and S. W. Hunt (2010), Updating the conceptual model for fine particle mass emissions from combustion systems Allen L. Robinson, J. Air Waste Manage. Assoc., 60(10), 1204-1222, doi:10.3155/1047-3289.60.10.1204.

Sahu, L. K., et al. (2012), Emission characteristics of black carbon in anthropogenic and biomass burning plumes over California during ARCTAS-CARB 2008, J. Geophys. Res., 117, D16302, doi:10.1029/2011JD017401.

Saleh, R., C. J. Hennigan, G. R. McMeeking, W. K. Chuang, E. S. Robinson, H. Coe, N. M. Donahue, and A. L. Robinson (2013), Absorptivity of brown carbon in fresh and photo-chemically aged biomass-burning emissions, Atmos. Chem. Phys., 13(15), 7683-7693, doi:10.5194/acp-13-7683-2013.

Schwarz, J. P., et al. (2006), Single-particle measurements of midlatitude black carbon and light-scattering aerosols from the boundary layer to the lower stratosphere, J. Geophys. Res., 111, D16207, doi:10.1029/2006JD007076.

Schwarz, J. P., et al. (2008), Measurement of the mixing state, mass, and optical size of individual black carbon particles in urban and biomass burning emissions, Geophys. Res. Lett., 35, L13810, doi:10.1029/2008GL033968.

Slowik, J. G., et al. (2007), An inter-comparison of instruments measuring black carbon content of soot particles, Aerosol Sci. Technol., 41(3), 295-314, doi:10.1080/02786820701197078.

Sorooshian, A., S. M. Murphy, S. Hersey, R. Bahreini, H. Jonsson, R. C. Flagan, and J. H. Seinfeld (2010), Constraining the contribution of organic acids and AMS m/z 44 to the organic aerosol budget: On the importance of meteorology, aerosol hygroscopicity, and region, Geophys. Res. Lett., 37, L21807, doi:10.1029/2010GL044951. 
Spackman, J. R., J. P. Schwarz, R. S. Gao, L. A. Watts, D. S. Thomson, D. W. Fahey, J. S. Holloway, J. A. de Gouw, M. Trainer, and T. B. Ryerson (2008), Empirical correlations between black carbon aerosol and carbon monoxide in the lower and middle troposphere, Geophys. Res. Lett., 35, L19816, doi:10.1029/2008GL035237.

Spracklen, D. V., L. J. Mickley, J. A. Logan, R. C. Hudman, R. Yevich, M. D. Flannigan, and A. L. Westerling (2009), Impacts of climate change from 2000 to 2050 on wildfire activity and carbonaceous aerosol concentrations in the western United States, J. Geophys. Res., 114, D20301, doi:10.1029/2008JD010966.

Stephens, M., N. Turner, and J. Sandberg (2003), Particle identification by laser-induced incandescence in a solid-state laser cavity, Appl. Opt., 42(19), 3726, doi:10.1364/AO.42.003726.

Subramanian, R., C. A. Roden, P. Boparai, and T. C. Bond (2007), Yellow beads and missing particles: Trouble ahead for filter-based absorption measurements, Aerosol Sci. Technol., 41(6), 630-637, doi:10.1080/02786820701344589.

Subramanian, R., et al. (2010), Black carbon over Mexico: The effect of atmospheric transport on mixing state, mass absorption cross-section, and BC/CO ratios, Atmos. Chem. Phys., 10(1), 219-237, doi:10.5194/acp-10-219-2010.

Sueper, D., P. F. DeCarlo, A. C. Aiken, and J. L. Jimenez (2013), ToF-AMS high resolution analysis software. [Available at http://cires.colorado. edu/jimenez-group/wiki/index.php/ToF-AMS_Analysis_Software.]

Sullivan, A. P., A. A. May, T. Lee, G. R. McMeeking, S. M. Kreidenweis, S. K. Akagi, R. J. Yokelson, S. P. Urbanski, and J. L. Collett Jr. (2014), Airborne characterization of smoke marker ratios from prescribed burning, Atmos. Chem. Phys. Discuss., 14(8), 11,715-11,747, doi:10.5194/ acpd-14-11715-2014.

Turpin, B. B. J., and H.-J. H. Lim (2001), Species contributions to PM2.5 mass concentrations: Revisiting common assumptions for estimating organic mass, Aerosol Sci. Technol., 35(1), 602-610, doi:10.1080/02786820119445.

Urbanski, S. P. (2013), Combustion efficiency and emission factors for wildfire-season fires in mixed conifer forests of the northern Rocky Mountains, US, Atmos. Chem. Phys., 13(14), 7241-7262, doi:10.5194/acp-13-7241-2013.

Van der Werf, G. R., J. T. Randerson, L. Giglio, G. J. Collatz, M. Mu, P. S. Kasibhatla, D. C. Morton, R. S. DeFries, Y. Jin, and T. T. van Leeuwen (2010), Global fire emissions and the contribution of deforestation, savanna, forest, agricultural, and peat fires (1997-2009), Atmos. Chem. Phys., 10(23), 11,707-11,735, doi:10.5194/acp-10-11707-2010.

Ward, D. E., and C. C. Hardy (1991), Smoke emissions from wildland fires, Environ. Int., 17(2-3), 117-134, doi:10.1016/0160-4120(91)90095-8

Watson, J. G., J. C. Chow, and L.-W. A. Chen (2005), Summary of organic and elemental carbon/black carbon analysis methods and intercomparisons, Aerosol Air Qual. Res., 5(1), 65-102.

Watson, J. G. J., et al. (2011), Particulate emission factors for mobile fossil fuel and biomass combustion sources, Sci. Total Environ., 409(12), 2384-2396, doi:10.1016/j.scitotenv.2011.02.041.

Weimer, S., M. R. Alfarra, D. Schreiber, M. Mohr, A. S. H. Prévôt, and U. Baltensperger (2008), Organic aerosol mass spectral signatures from wood-burning emissions: Influence of burning conditions and wood type, J. Geophys. Res., 113, D10304, doi:10.1029/2007JD009309.

Westerling, A. L., H. G. Hidalgo, D. R. Cayan, and T. W. Swetnam (2006), Warming and earlier spring increase western U.S. forest wildfire activity, Science, 313(5789), 940-943, doi:10.1126/science.1128834.

Wiedinmyer, C., B. Quayle, C. Geron, A. Belote, D. McKenzie, X. Zhang, S. O’Neill, and K. K. Wynne (2006), Estimating emissions from fires in North America for air quality modeling, Atmos. Environ., 40(19), 3419-3432, doi:10.1016/j.atmosenv.2006.02.010.

Wiedinmyer, C., S. K. Akagi, R. J. Yokelson, L. K. Emmons, J. A. Al-Saadi, J. J. Orlando, and A. J. Soja (2011), The Fire INventory from NCAR (FINN): A high resolution global model to estimate the emissions from open burning, Geosci. Model Dev., 4(3), 625-641, doi:10.5194/gmd-4-625-2011.

Yamasoe, M. A., P. Artaxo, A. H. Miguel, and A. G. Allen (2000), Chemical composition of aerosol particles from direct emissions of vegetation fires in the Amazon Basin: Water-soluble species and trace elements, Atmos. Environ., 34(10), 1641-1653, doi:10.1016/S1352-2310(99)00329-5.

Yelverton, T. L. B., M. D. Hays, B. K. Gullett, and W. P. Linak (2014), Black carbon measurements of flame-generated soot as determined by optical, thermal-optical, direct absorption, and laser incandescence methods, Environ. Eng. Sci., 31(4), 209-215, doi:10.1089/ ees.2014.0038.

Yokelson, R. J., D. W. T. Griffith, and D. E. Ward (1996), Open-path Fourier transform infrared studies of large-scale laboratory biomass fires, J. Geophys. Res., 101(D15), 21,067-21,080, doi:10.1029/96JD01800.

Yokelson, R. J., J. G. Goode, D. E. Ward, R. A. Susott, R. E. Babbitt, D. D. Wade, I. Bertschi, D. W. T. Griffith, and W. M. Hao (1999), Emissions of formaldehyde, acetic acid, methanol, and other trace gases from biomass fires in North Carolina measured by airborne Fourier transform infrared spectroscopy, J. Geophys. Res., 104(D23), 30,109-30,125, doi:10.1029/1999JD900817.

Yokelson, R. J., et al. (2007), Emissions from forest fires near Mexico City, Atmos. Chem. Phys., 7(21), 5569-5584, doi:10.5194/acp-7-5569-2007.

Yokelson, R. J., et al. (2009), Emissions from biomass burning in the Yucatan, Atmos. Chem. Phys., 9(15), 5785-5812, doi:10.5194/acp-9-5785-2009.

Yokelson, R. J., et al. (2013a), Coupling field and laboratory measurements to estimate the emission factors of identified and unidentified trace gases for prescribed fires, Atmos. Chem. Phys., 13(1), 89-116, doi:10.5194/acp-13-89-2013.

Yokelson, R. J., M. O. Andreae, and S. K. Akagi (2013b), Pitfalls with the use of enhancement ratios or normalized excess mixing ratios measured in plumes to characterize pollution sources and aging, Atmos. Meas. Tech., 6(8), 2155-2158, doi:10.5194/amt-6-2155-2013.

Yu, J. Z., J. Xu, and H. Yang (2002), Charring characteristics of atmospheric organic particulate matter in thermal analysis, Environ. Sci. Technol., 36(4), 754-761, doi:10.1021/es015540q 